\title{
La moralización del Leandro de Boscán: orígenes, difusión e interpretación de una fábula
}

\author{
Bienvenido Morros Mestres \\ Universidad Autónoma de Barcelona \\ bienvenido.morros@uab.cat
}

Recepción: 16/07/2013, Aceptación: 03/10/2013, Publicación: 20/12/2013

\section{Resumen}

Boscán lleva a cabo una evidente moralización de la fábula de Leandro y Hero al eliminar determinados elementos de su fuente principal, el epilio de Museo, y añadir otros que no había encontrado en el poema griego. Suprime, por ejemplo, la escena erótica en que Leandro descińe la cinta de Hero y amplía en cambio la de la unción del cuerpo que la novia lleva a cabo en el cuerpo del novio especialmente a través de otras fuentes clásicas (la unción de Eneas por su madre Venus para convertirse en un dios) y también bíblicas (la unción de Cristo en Betania por una mujer pecadora). Al final ha decidido salvar a los amantes al situarlos tras sus muertes por suicidio en los Campos Elisios cuando una de sus fuentes, Bernardo Tasso, los había ubicado no en esos lugares sino también en los bosques del mirto. Si el barcelonés ha moralizado la fábula es porque ha querido defender el amor conyugal por encima de otro tipo de amor, como ya había hecho en el libro II de sus Obras (Barcelona, 1543) y para conmemorar su boda con Ana Girón de Rebolledo en septiembre de 1939.

\section{Palabras clave}

poesía clásica y del Renacimiento; los Evangelios; mitología; filosofía del amor; el amor conyugal; poesía comparada

\begin{abstract}
The moralization of Boscan's Leandro: sources, diffusion and interpretation of a fable

Boscan carries out a clear moral standards to the fable of Leandro and Hero by eliminating certain elements of its main source, the epilio of Museum, and add others that had not found in the Greek poem. Deleted, for example, the scene in which Leander has released the Hero's belt and expands instead of the anointing of the body that the bride carried out in the body of the boyfriend, especially through other classical sources (the anointing of Aeneas by his mother Venus to become a God) and also biblical (the anointing of Christ at Bethany for a sinful woman). At the end she decided to save the lovers by placing them
\end{abstract}


after their deaths by suicide in the Elysian fields when one of their sources, Bernardo Tasso, had located them not in those places but also in the forests of Myrtle. If Boscán has moralized the fable it is because he wanted to defend the conjugal above another type of love, as he had done in book II of his works (Barcelona, 1543) and to commemorate your wedding with Ana Girón de Rebolledo in September 1939.

\section{Keywords}

poetry; classical and Renaissance; the Gospels; mythology; philosophy of love; marital love; comparative poetry

\section{Decid a todos que ha sido el ruiseñor}

Cuando Boscán decide en el año 1539 componer una fábula mitológica no tiene ninguna duda sobre cuál de las que conocía iba a elegir. Y no la tiene porque buscaba una fábula que se aviniera con la idea del amor conyugal que se había forjado desde que empezó la relación con la que iba a ser su esposa, la valenciana Ana Girón de Rebolledo. Es difícil fijar con exactitud la fecha en que el barcelonés pensó en ese nuevo tipo de amor, que ya había alabado y ponderado en el libro II de sus obras, un libro que habría terminado seguramente, como la epístola a Diego Hurtado de Mendoza, en que declara haberse casado "con una mujer», al poco de haber contraído matrimonio con dońa Ana en septiembre de 1539.

En esa decisión pudo también haber influido el posible diálogo con Bernardo Tasso en algún momento de 1537 o 1539, los años en que se ha supuesto que el poeta italiano estuvo en España, y más concretamente en Barcelona ${ }^{1}$. Tasso, como es sabido, había publicado en el tercer libro de sus Amori, en Venecia el ańo 1537, la "Favola di Leandro e d'Ero», para la que había elegido el verso suelto, el mismo que adopta unos años después nuestro poeta.

Boscán debió tomar la decisión a la que aludíamos al principio después de conocer el epilio de Museo, que podía haber leído en su versión original, o también en alguna de las dos traducciones latinas, la de Aldo Manuzio o la más poética de

1. Giovanni Caravaggi (2009: 142): «... también consta que Bernardo Tasso fue enviado a la corte española, en algunas misiones diplomáticas; por ejemplo, en 1537, para pedir la liberación de Filippo Strozzi, que había sido encarcelado en Florencia; consta que se embarcó en Génova, desembarcando en Barcelona; en 1539 cumplió otro viaje, siguiendo un viaje parecido» (debemos la referencia a la siempre generosa
Eugenia Fosalba). Marcelino Menéndez Pelayo (1945: 304) también había aludido a la estancia del poeta italiano en España pero sin ser tan preciso como Caravaggi: «Bernardo Tasso, que había acompañado al Emperador en la jornada de Túnez, estuvo dos veces en España, en 1537 y 1539, y conocía perfectamente nuestra lengua. Es muy verosímil que tuviese relaciones con Boscán, como seguramente las tuvo con Garcilaso». 
Guillermo de Mara, que ya habían tenido amplia circulación, la primera desde finales del siglo XV (entre 1497 y 1498) y la segunda a partir de 1511. En unos casos parece seguir el original griego pero en otros, en cambio, ha utilizado muy claramente la versión de Guillermo de Mara².

El barcelonés debía de haber sintonizado con el poema de Museo porque en su tratamiento del amor reconoció una gran afinidad con el que él por esas fechas (o quizá un poco antes) daba al que le inspiraba la dama valenciana. El gramático griego, como comprobaremos en seguida, en tiempos en que el Cristianismo ya se había difundido y extendido para ejercer cierta influencia entre sus contemporáneos, decide disfrazar desde el segundo verso de su poema el amor absolutamente carnal de sus dos personajes de uno conyugal. Es un ejercicio que parece llevar a cabo por sí mismo el poeta griego al transformar toda una tradición, desde una probable fuente helenística a la que se remonta, que presentaba esos amores como desmesurados y excesivamente apasionados.

\section{Orígenes de la fábula}

La fábula de Leandro y Hero no debió de ser muy antigua porque no la mencionan los primeros mitógrafos griegos: al crearse posiblemente como leyenda local en torno a un faro con el nombre de "torre de Hero» en la zona en que transcrurre parte de su acción (Estrabón, Geografía, 13, 1,22) no pudo ser anterior al primer faro documentado en la Antigüedad, que es el de Alejandría, construido hacia el año 280 a. de C. Es después de esta fecha cuando los poetas de la época o de épocas posteriores (mayormente helenística) pudieron haberla convertido en tema de sus obras líricas, épicas o dramáticas. No hay más constancia de esas obras que unos pocos versos conservados en tres papiros ya bastante tardíos. De los tres papiros que se han utilizado para la reconstrucción de esas obras el más antiguo (el Ryland 486, del siglo I d. de C) es el que ofrece una información más precisa sobre nuestra fábula al incluir entre los diez hexámetros mutilados dos veces el nombre de Leandro $(\Lambda \alpha \alpha v \delta \rho o v$ y $\Lambda \alpha \alpha \delta \rho \varepsilon)$ junto a otras palabras claves como

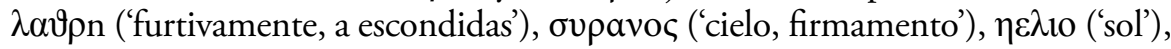
etc. Los otros dos papiros (el Oxirrinco 864 y el berlinés 21249), de los siglos III y IV-V d. de C. respectivamente, parecen también aludir a nuestra fábula al plantear con toda probabilidad algunos de sus temas más característicos, especialmente el del planto de una mujer a orillas del Helesponto sobre el cadáver de un náufrago ${ }^{3}$. Para simplificar la cuestión preferimos hablar de un solo poema perdido (y no de

2. Antonio Alvar Ezquerra (2007: 127) cree que Boscán se basó exclusivamente en el original griego.

3. Para el contenido de cada uno de esos papiros véanse José Guillermo Montes Cala (1994: 24-25); y Antonio Villarrubia (2000: 68); y
Antonio Ruiz de Elvira (2003: xii). El último de los autores citados es el único que cuestiona la existencia de este poema helenístico porque cree que el fragmento del papiro Rylands, al ser muy deficitario, no la prueba ni demuestra en ningún caso. Pero al menos admite que el frag- 
varios), posiblemente representado por los papiros Ryland y el berlinés, al haber transmitido los dos un poema en hexámetros: no así el Oxirrinco, que parece contener restos de una tragedia helenística.

Pero podemos intentar la reconstrucción de ese poema perdido estudiando con cierto detalle los autores más antiguos que lo han usado por igual en cada una de sus obras. Antes que Museo hay tres autores que suministran datos muy importantes para esa posible reconstrucción. Esos autores pertenecen aproximadamente al período imperial (entre el siglo i a. de C. y el I d. de C.), y son Virgilio, Ovidio y Antípatro de Tesalónica (Antología griega, VII, 666; IX, 215). Ninguno de los tres autores (ni tan siquiera el macedonio, como veremos enseguida) parece aludir al matrimonio secreto de nuestros amantes. De los tres el que menos se ha estudiado es Antípatro, cuyos epigramas conviene releer porque aportan detalles que demuestran haber seguido de manera muy obvia y clara la misma versión que Museo para su epilio. El primero de los dos epigramas griegos trata cuestiones relacionadas directamente con los amantes de nuestra fábula:

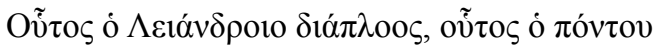

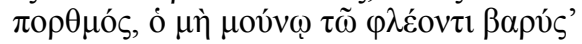

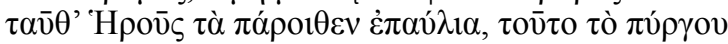

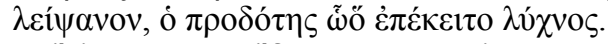

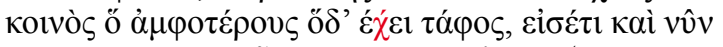

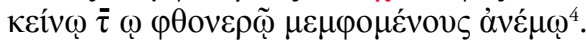

['Este es el lugar que atravesaba Leandro, este el estrecho de mar, molesto no sólo para uno de los amantes. Aquí Hero había tenido su morada, aquí están las ruinas de la torre, aquí está la lámpara traidora, [los amantes] tienen una sepultura común para los dos, aún ahora éstos están haciendo reproches al envidioso viento’]

El poeta macedonio (en unos cuantos siglos anterior a Museo) ofrece dos particularidades que llaman a primera vista la atención: la referencia a la famosa lámpara que usaba Hero para guiar a Leandro por la noche y la mención de una misma sepultura para los dos amantes. Denomina a la lámpara en cuestión con un adjetivo que pertenece a un campo semántico muy similar al del adjetivo

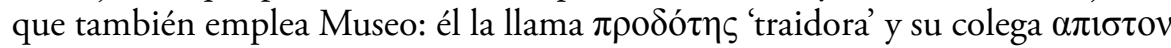
'desleal, pérfida' (Guillermo de Mara lo traduce por «infidam», 'infiel'). Es fácil, pues, deducir que los dos autores griegos remontan de forma independiente a una fuente común (el poema alejandrino) que ya utilizaba uno de los dos adjetivos para la lámpara de Hero. Si ya lo hace el misterioso autor es porque la consideraba (al dejarse apagar por una ráfaga de viento) responsable de la muerte de los amantes. Boscán, como veremos, invierte esa tradición y llama a la famosa

mento en cuestión debió versar sobre nuestra fábula porque recoge dos veces el nombre de Leandro.
4. Citamos por W. R. Paton1 (970: 354); el epigrama también lo reproduce Francisca Moya del Baño (1969: 212). 
lámpara «testigo fiel y dulce mensajera» (2770), siguiendo a otros poetas de la misma antología que también le dan ese mismo tratamiento $(\mathrm{V}, 8)^{5}$.

El poeta bizantino Agatías Escolástico, que debió de componer sus epigramas antes del año 565 (es por tanto posterior en unos cuantos ańos a Museo), escribió uno en concreto en que también se refiere a la lámpara de nuestra fábula para tratarla igualmente de infiel a sus amantes (pero sin llegar nunca a calificarla así) por considerarla fabricada por un Hefesto resentido con su esposa adúltera, la diosa Afrodita (Antología griega, V, 263):

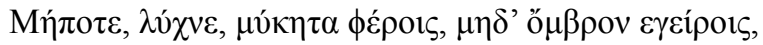

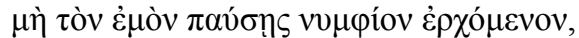

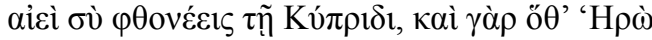

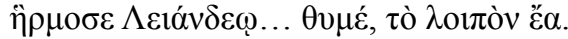

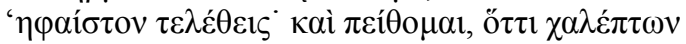

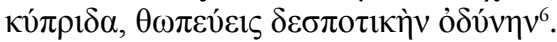

['Nunca, lámpara, te llenes de hongos ni suscites lluvias, ni impidas venir a mi esposo. Siempre tú has odiado a Cipris, y ciertamente cuando Hero se unió con Leandro... Corazón mío, deja todo lo demás. Tú eres favorable a Hefesto y creo que, vejando a Cipris, tú halagas a su señor que sufre’'].

Es casi seguro que Agatías había leído a Museo porque pone en boca de la muchacha, para hacer que se dirija a su amado, el término voupíov, quizá pensando en el estado civil que tienen Leandro y Hero en el epilio griego (el gramático que lo compuso lo llega a usar hasta seis veces). Para referirse al tipo de relación de nuestros amantes ha empleado el verbo $\alpha \rho \mu o \tau \tau \omega$, que en algunos casos también podría traducirse por 'desposarse'.

Antípatro de Tesalónica, como hemos anunciado antes, presenta a Hero y Leandro enterrados en una misma sepultura dando a entender que seguían juntos en la muerte como lo habían estado en vida. No cabe descartar en un principio que el poeta macedónico hubiera imaginado ese particular entierro de nuestros amantes pensando en otros autores de la Antología griega que al componer epigramas fúnebres también lo habían previsto para sus personajes (especialmente VII, 378 y 434). Pero su reiteración en prácticamente todas las versiones posteriores de la fábula invita a suponer que ya podía aparecer en el poema alejandrino de donde lo habrían tomado por separado Antípatro y los otros autores, tanto medievales como renacentistas.

En el siglo Iv Ausonio compuso un breve poema (Cupido cruciatus) en que

5. Uno de esos poetas es Estatilio Flaco, tal vez de origen romano, de los siglos I a. de C.al I d. de C., quien llama a la lámpara ( $\lambda u ́ \chi v o v)$

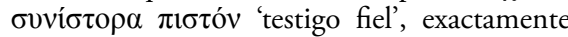
igual que Boscán ( W. R. Paton 1994: 130).
Entre los epigramas iniciales de ese libro $\mathrm{V}$ de la Antología griega se alude también a la lámpara como testigo o confidente pero con otros calificativos (V, 4, 7, 8 etc).

6. W. R. Paton (1994 264). 
narra el descenso de Cupido a los «lugentes campi» y su encuentro en sus dominios con una serie de heroínas que no pueden olvidar las desgracias que habían padecido en vida. Las heroínas lo reconocen nada más verlo aparecer y tras contemplar sus heridas lo hacen responsable a él de haberlas sufrido. Todas lo rodean y lo arrastran a un bosque de mirtos para crucificarlo en uno de sus árboles más altos. Incluso Venus participa en la tortura de su hijo al recordar que por su maldad se vio atrapada entre unas redes cuando compartía su lecho con Marte. Las heroínas al final deciden liberar a su prisionero porque prefieren culpar a los hados de sus desdichas.

En el prefacio en prosa que incluye al principio del poema Ausonio se dirige a un personaje desconocido a quien llama "hijo" no en sentido literal sino más bien afectuoso. Le confiesa que ha compuesto su obra (a la que llama "eclogae») a partir de un cuadro en que había visto a Cupido crucificado por algunas de las heroínas que Virgilio había situado en los «lugentes campi»:

Treveris quippe in triclinio Zoili fucata est pictura haec: Cupidinem cruci affigunt mulieres amatrices, non istae de nostro saeculo, que sponte peccant, sed illae heroicae, quae sibi ignoscunt et plectunt deum, quorum partem in lugentibus campis Maro noster enumerat ${ }^{7}$.

['En Treveris en efecto, en el comedor de Zoilo, hay esta pintura: mujeres enamoradas clavan a Cupido en la cruz, y no son como estas de nuestra época, que pecan de buen grado, sino aquellas heroínas que se perdonan a sí mismas y castigan al dios, algunas de las cuales menciona nuestro Marón en los campos de los que se lamentan'].

Al principio de su poema Ausonio vuelve a citar a Virgilio al describir el lugar en el que transcurre la acción y al mencionar a las heroínas que en medio de lágrimas lo recorren mostrando aún las señales de la muerte que sufrieron (al igual que hace Dido en la Eneida):

Aëris in campis, memorat quos musa Maronis, Myrteus amentes ubi lucus opacat amantes,

Orgia ducebant heroides et sua quaeque,

Ut quondam occiderant, leti argumenta gerebant,

Errantes silva in magna et sub luce maligna [...]

Omnia quae lacrimis et amoribus anxia maestis

Exercent memores obita iam morte dolores:

Rursus in amissum revocant heroidas aevum ${ }^{8}$.

['En los campos aéreos, que la musa de Marón nos recuerda, donde un bosque de mirtos da sombra a los locos amantes, las heroínas celebraban sus misterios y, errando por el gran bosque y bajo una luz escasa, cada una llevaba las marcas de la muerte que en otro tiempo había sufrido [...] Todas las que angustiadas por las

8. Ausonio (1971: 596-8). 
lágrimas y los tristes amores recuerdan en la muerte después de muertas los dolores: las heroinas vuelven a evocar la vida perdida'].

Ausonio menciona también a Hero en esos campos en el momento en que la muchacha se arroja desde su torre al mar llevando su lámpara con una luz que despide o huele a humo:

Fert fumida testae

Lumina Sestiaca praeceps de turre puella

('Lleva la muchacha la luz humosa de la antorcha al precipitarse desde su torre de Sestos') $)^{9}$.

El poeta burdulense parece dar a entender que Hero tiene todavía la lámpara encendida (símbolo de su amor por Leandro) y que su luz exhala el humo tras el contacto con el agua del mar que no ha conseguido apagarla. Si emplea el oxímoron "fumida... lumina» es porque pretende subrayar que la luz sigue brillando a pesar de haberse mojado. No puede ofrecer otra interpretación esa figura retórica cuando sitúa a la heroína en un lugar después de la muerte en que conserva su amor por Leandro. Si no lo incluye a él en esos campos es porque el tipo de poema que compone no se lo permite: en sus dominios sólo hace que aparezcan mujeres y no hombres porque son ellas las que desean vengarse de Cupido. Pero está claro que Ausonio sigue la tradición del poema alejandrino que consideraba que el amor de sus personajes sobrevivía a su muerte.

Si es así como supongo Museo habría, pues, suprimido ese detalle (el de los amantes que comparten la misma sepultura y que aman más allá de sus muertes) porque ha dejado claro antes de llegar al final de su poema que al apagarse la lámpara también se había extinguido en el mar la vida y el amor de Leandro. El gramático griego debía haber leído en su fuente alejandrina que el amor de sus dos amantes era un amor manifiestamente carnal y habría sentido la necesidad (y también la tentación) de considerarlo tan efímero como la vida humana: de hecho, conserva muchos de los calificativos (como hace también Ovidio en sus heroidas) que el poeta alejandrino habría usado para definir ese tipo de amor. Es precisamente la naturaleza lujuriosa del amor de sus amantes la que propicia la interpretación que hace Museo de la fábula, y es esa interpretación la que acaba imponiéndose, como veremos más adelante, en la Edad Media: la interpretación de Museo pero sin Museo (porque el poeta griego no parece que fuera muy conocido en ese período de nuestra civilización occidental).

Pero el autor que había creado la fábula (por supuesto nunca de la nada) debía de haber considerado el amor carnal de nuestros personajes tan desmesurado que lo creía capaz de sobrevivir a sus propias muertes y desafiar de esa ma-

9. Ausonio (1971: 598-600). 
nera todas las leyes de la naturaleza. Con su epigrama Antípatro de Tesalónica parecía certificar esta suposición porque en sus versos finales no sólo menciona la sepultura común de los dos amantes sino también sus quejas ya muertos al viento que había apagado la lámpara con la que la amada por la noche había guiado al amado.

En sus heroidas Ovidio, en cambio, introduce una referencia muy puntual en la que parece dar a entender que el amor de Leandro se extingue a la vez que su vida. En la primera de las dos epístolas Leandro, al contemplar la posibilidad de sucumbir a la fuerza de las olas, porque no está dispuesto a esperar más tiempo para cruzar el Helesponto, asegura que su muerte pondrá fin también a su amor ansioso:

Aut mihi continget felix audacia salvo,

Aut mors solliciti finis amoris erit! (vv. 195-196) ${ }^{10}$

['O tendrá un éxito feliz mi osadía al llegar indemne o la muerte será el final de mi amor ansioso'].

Ovidio podría haberse limitado en estos versos a reproducir el poema helenístico que ha usado para sus dos heroidas o podía haberlos añadido por su cuenta. La coincidencia con Museo en ese punto parece confirmar la primera posibilidad pero la discrepancia con Virgilio y Antípatro de Tesalónica puede también cuestionarla. Es difícil decantarse por una de las dos posibilidades cuando hay el mismo tanto por ciento para hacerlo o dejar de hacerlo.

Creo poder aducir un argumento que si no certifica la segunda definitivamente al menos la convierte en la más verosímil y plausible. Para la fábula de Ifis y Anáxarete Ovidio se ha inspirado claramente en un idilio griego atribuido a Teócrito y de época posiblemente helenística. En ese idilio, conservado íntegramente, el amante se dirige a su amado para asegurarle en el preciso momento en que está a punto de ahorcarse en la puerta de su casa que ese deseo insatisfecho que le ha llevado a tomar tan trágica decisión seguirá vivo incluso después de haber bebido las aguas del olvido:

$\gamma \alpha \dot{\rho} \sigma \varepsilon$

$\kappa \tilde{\omega} \rho \varepsilon \theta \dot{\varepsilon} \lambda \omega \lambda v \pi \varepsilon \bar{i} v \pi \circ \theta 0 \rho \omega ́ \mu \varepsilon v o \varsigma, \dot{\alpha} \lambda \lambda \dot{\alpha} \beta \alpha \delta i \zeta \omega$

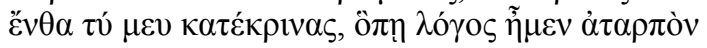

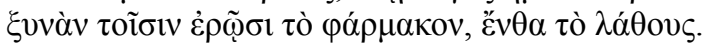

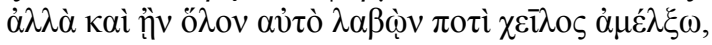

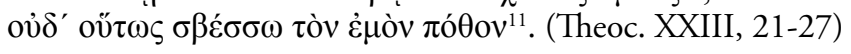

('Ciertamente no quiero, mancebo, molestarte con mi presencia. Pero me encamino al lugar al que tú me has condenado, adonde dicen que está para los enamorados

10. Ovidio (1950: 132).

11. Uso la edición de J. M. Edmonds (1977: 280). 
el remedio común de sus pesares, al lugar en el que se halla el olvido; pero aunque lo lleve yo a mis labios y lo beba entero, ni aun así apagaré mi deseo').

Ovidio, en cambio, acaba convirtiendo este tópico sobre el poder del amor más allá de la muerte y el olvido en una afirmación bastante ambigua que ha dado pie a interpretaciones muy diferentes (no se sabe si en su versión la pena por amor sobrevive o no a la muerte, porque puede durar sólo hasta el último momento de vida o incluso mucho después de haberla perdido):

Vincis, Anaxarete, neque erunt tibi taedia tandem

Ulla ferenda mei $[\ldots]$

Non tamen ante tui curam excessisse memento

Quam vitam $[\ldots]^{12}$

['Vences, Anajárete, y finalmente tú no tendrás que sufrir más enfados por mí [...]

Recuerda que no abandonaré la preocupación amorosa por ti antes que la vida’].

Para nuestra fábula Ovidio pudo también transformar de esta misma manera el tópico del amor post mortem. Si está bastante claro que lo hace en una fábula ¿por qué no pudo hacerlo en otra?

Pero es también Antípatro de Tesalónica (llamado también de Macedonia) quien podría ser el primero en aludir al estado civil de Leandro y Hero cuando para referirse a nuestro protagonista lo llama óvép $\rho$ (cuyo genitivo es $\alpha v \delta \rho o ́ \varsigma$ ), en un epigrama que presenta el Helesponto como escenario de otro trágico final (al margen de la ninfa Helle que dio nombre al estrecho de mar):

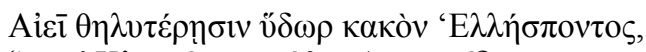

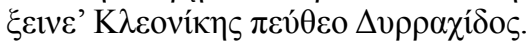

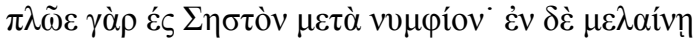

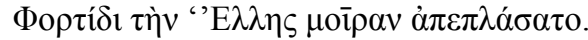

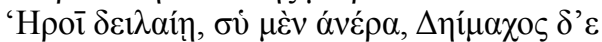

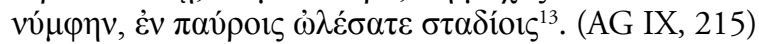

['Siempre, forastero, es el agua del Helesponto funesta para la delicada mujer. Pregúntaselo a Cleonice de Dirraquio. En verdad estando navegando hacia Sestos para ir al lado de su esposo el negro barco en que había partido tuvo el mismo destino que la ninfa Hele. Pobre Hero, tú perdiste a tu amante, Deímaco, en cambio, a su esposa en muy pocos estadios'].

Antípatro parece entender ảvépa y vú $\mu \varphi \eta v$ con sentidos diferentes porque presenta a sus respectivas parejas (Leandro y Cleonice de Dirraquio), que com-

12. Cito por la edición de Bartolomé Segura Ramos, con traducción de Antonio Ruiz de Elvira (1983: 157).
13. W. R. Paton (1994: 112) traduce àvépa por «husband», mientras Guy Soury (1957) y Guillermo Galán Vioque (2004: 151) lo hacen respectivamente por "amant» $\mathrm{y}$ «amante». 
parten el mismo destino de haber perdido a un ser querido en el Helesponto, también con diferentes estados civiles: como amante en el primer caso y esposo (o marido) en el segundo. Por eso el macedonio utiliza la partícula adversativa $\delta \varepsilon$ ('pero, sin embargo, en cambio'): establece de ese modo la única diferencia que reconoce en una pareja que tienen en común tantas cosas (pero no su estado civil).

Museo, por ejemplo, nunca recurre a la palabra $\alpha v \eta ́ \rho$, que propiamente significa 'hombre, varón' (pero también en algunos casos 'amante', 'esposo o marido'), para denominar a Leandro cuando lo trata ya de esposo o marido de Hero (que es casi siempre). Para esos sentidos emplea términos más adecuados y también menos ambiguos, que son voupros (vv. 260, 267, 268, 269, 283 y 335),

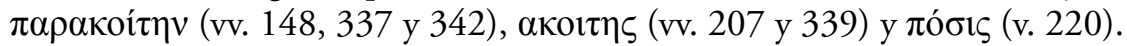

El profesor de poesía Eilhardo Lubino, a principios del siglo XviI, da a la imprenta su versión completa al latín de la Antología griega (Heildelberg, 16031604). Incluye, por supuesto, los dos epigramas del poeta macedonio; y, en el primero de los citados, emplea la palabra "virum» para traducir el óvép $\alpha$ del original, cuando para señalar el estado civil de Deímaco opta por «sponsum»:

Semper mulieribus aqua malum Hellespontus,

Hospes. Cleonicam interroga Dyrrachidem.

Navigat enim Sestum ad sponsum. In nigra vero

Oenaria navi Helles fatum effinxit.

Hero infelix, tu quidem virum, Deimachus vero

Sponsam, in paucis perdidistis stadiis ${ }^{14}$.

['Siempre, forastero, el agua del Helesponto fue adversa para las mujeres. Interroga a Cleonice de Dirraquio. Navegó, en efecto, a Sesto hacia su esposo, pero imitó en negra nave onaria el hado de Heles. Desgraciada Hero, tú perdiste sin duda al hombre, pero Deímaco a la esposa, en pocos estadios'].

Lubino ha sido bastante preciso al buscar la palabra que mayor equivalencia tuviera con el sustantivo $\alpha v \eta ́ \rho$, porque sabía que «vir» se usaba con una amplia gama de sentidos, ya como 'varón, hombre adulto, fuerte', pero también como 'marido', y prácticamente nunca como 'amante'. En cualquier caso, nuestro traductor conserva el mismo contraste que el original entre «virum» $\mathrm{y}$ «sponsam», indicándolo en su caso con la partícula "vero».

En el siglo x, Remigio de Auxerre, en su comentario de la obra De nuptiis Philologiae et Mercurii de Marciano Capella, al explicar el sentido de «Hermaphroditus», usa esas dos palabras, en griego y en latín, para definir la parte masculina del andrógino, que contrapone a la femenina, que explica asimismo con otras dos palabras también en esas dos lenguas:

14. Este epigrama figura entre los poemas inMuseo del siglo xviII: Musaei Grammatici De cluidos en los preeliminares de las ediciones de Hero et Leandro Carmen, 1731, Leiden, s. f. 
Ermafroditos autem dicimus homines utriusque sexus quos et androgios vocamus; aner enim vel ander Graece vir, ginex mulier ${ }^{15}$.

['Hermafrodito llamamos sin embargo a los hombres de uno y otro sexo a los cuales también denominamos andrógino; åvì $\rho$ o ander en griego es 'vir', y Yvuๆ 'mujer'].

Otro de los poetas importantes (es Virgilio) para la reconstrucción del origen de nuestra fábula (por ser el primero en abordarla) ofrece en los versos de sus Geórgicas (III, 258-263) un dato que no hacía sino confirmar el posible tratamiento que el misterioso autor del texto alejandrino había dado a este tema clásico. Tras alegar el ejemplo de Leandro (al que nunca el poeta latino llama por ningún nombre) como el de un amor que iguala a los seres humanos con los animales Virgilio decide caracterizarlo con un adjetivo que lo define y distingue de cualquier otro. El adjetivo que elige es «durus» y parece darle el sentido de 'irrefrenable, irresistible’:

Quid iuvenis, magnum cui versat in ossibus ignem

Durus amor? Nempe abruptis turbata procellis

Nocte natat caeca serus freta (III, 258-260) ${ }^{16}$.

['¿Qué joven al que el amor duro introduce en los huesos un gran fuego? Ciertamente, nada cada noche el ciego mar alterado por tormentas intratables...'].

Un poeta que era amigo de Agatías de Mirina, Pablo Silenciario, y que por tanto debió de haber leído a Museo, compone un epigrama (Antología griega, V, 293) en el que en cambio demuestra conocer este pasaje de las Geórgicas cuando

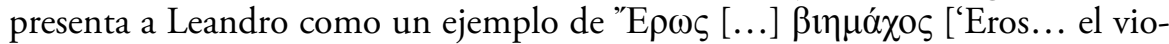
lento'] (v. 1) y غ̇ $\rho \omega \mu \alpha v i ́ n s$ ['eromanía o locura amor'] (v. 3) por haber sido capaz de hacer frente al nocturno oleaje. El poeta macedonio parece haber ofrecido su versión del «amor durus» en la que sin embargo no aduce para nada el amor de Hero porque quizá no lo considera del mismo tipo que el de su amante.

Virgilio vuelve a usar ese mismo adjetivo (de "durus») en su gran poema, la Eneida, cuando narra el descenso de su protagonista - acompañado por la sibila de Cumas - al Hades, para identificar el tipo de amor que experimentan las sombras que ya han cruzado el río de la muerte (el Aqueronte) y se han quedado en los famosos «lugentes campi», a la sombra de una «myrtea... silva»:

Non procul hinc partem fusi monstrantur in omnem

Lugentes campi; sic illos nomine dicunt.

Hic quos durus amor crudeli tabe peredit

Secreti celant calles et myrtea circum

Silva tegit: curae non ipsa in morte relinquunt (VI, 440-444) ${ }^{17}$.

15. Jane Chance (1994: 274-275).

16. Virgilio (1988: 10).

París, Société d'Edition «Les Belles Artes», 1959,

17. Uso la edición de Henri Goelzer, Eneide, I, p. 180. 
['No lejos de aquí se muestran extendidos por una y otra parte los campos de los que lloran; así se los llama con este nombre. A estos a los que el duro amor ha consumido con una peste cruel ocultan las sendas secretas y a uno y otro lado una selva de mirtos los cubre: los cuidados no los abandonan ni en la misma muerte'].

En esos campos Virgilio sitúa sólo a mujeres que han amado de una forma tan desmesurada, que se han visto obligadas a suicidarse. En ellos, por ejemplo, describe a Dido primero corriendo y después reuniéndose junto a su marido Siqueo (y siempre con la herida abierta en el pecho). Sin embargo, no menciona para nada a Hero, a la que no hace ninguna referencia directa en los versos citados de las Geórgicas. Los autores medievales, como veremos más adelante, la acabarán considerando junto a su amante moradora habitual de esos campos que no siempre (y tampoco todos) saben diferenciar del infierno cristiano: rescataban de ese modo la antigua interpretación de la fábula al suponerlos en los lugares en que podían seguir amándose después de la muerte.

\section{La moralización de Museo}

El gramático griego del que sólo sabemos su nombre, Museo, a veces confundido con el discípulo de Orfeo, llegó a conocer esta versión de nuestra leyenda, que modificó porque debió considerarla demasiado obscena. Es de los autores antiguos el único que reproduce el episodio del enamoramiento de los personajes, y no hay modo de saber si ese es un episodio que toma del poema alejandrino perdido o que él se inventa por completo. Hemos dicho que Museo es el único en reproducir ese episodio pero no es el único en aludir al enamoramiento de nuestros personajes. Ovido también lo hace en sus dos heroidas, y a veces utilizando términos tan parecidos (a pesar de la diferencia de lengua) al poeta griego, que no es descabellado pensar que los dos los toman de forma independiente del poema helenístico perdido.

Museo denomina invencible al fuego (áıкń el corazón de Leandro al contemplar el de Abidos entre la multitud del templo a su amada; Ovidio, por su parte, en la segunda de las heroidas, pone en boca de Hero la afirmación de que ella arde en el mismo fuego que su amante pero que no tiene las mismas fuerzas que él para resistirlo: «urimur igne pari, sed sum tibi viribus impar» ['ardemos en un mismo fuego, pero no son las mismas nuestras fuerzas'] (XIX, 5). El gramático griego describe asimismo los cuatro sentimientos (Boscán los llama «accidentes contrarios», v. 282) de los que es presa Leandro en el preciso momento en que el muchacho se rinde a la belleza de la sacerdotisa

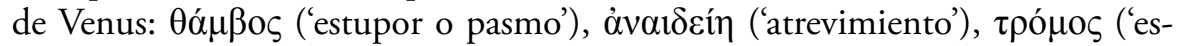
tremecimiento') y aīộs ('pudor, vergüenza'). Después lo presenta superando

18. Para el texto griego, hemos usado la edición bilingüe de Antonio Ruiz de Elvira (2003: 13). 
los tres que lo habían paralizado inicialmente gracias al atrevimiento: $\theta \dot{\alpha} \mu \beta \varepsilon \varepsilon$

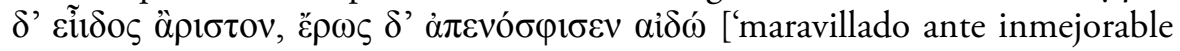
belleza, amor se llevó consigo la vergüenza']. También en la segunda de las heroidas Ovidio hace que vuelva a ser Hero quien recuerde en pugna prácticamente los mismos cuatro sentimientos: «pudor» ('vergüenza'), «timidus» ('miedoso'), «calor» ('ardor, desvergüenza') y «reverentia» ('recelo, recato'); pero no acaba de mostrar a la muchacha decidida a abandonar la vergüenza y la timidez: «Quid sequar, in dubiost» ['Estoy dudando cuál seguiré'] (IX, 171-174) ${ }^{18}$.

Para el episodio del enamoramiento, el gramático griego pudo haberse inspirado en varias de las llamadas novelas bizantinas, todas bastante anteriores. No hay casi ninguna duda de que llegó a tener muy en cuenta el Quéreas y Calirroe de Caritón de Afrodisias, con cuya obra coincide en casi todos los ingredientes que utiliza en el inicio de su epilio. El primero, y quizá menos importante, de esos ingredientes en común es la situación de la escena del enamoramiento en el marco de un fiesta en honor a Afrodita (pero el encuentro entre los amantes en la novela transcurre fuera del templo). El segundo es el amor recíproco que experimentan los amantes cuando intercambian las miradas. $Y$ aún un tercero radica en el matrimonio de los amantes a pesar de la rivalidad política entre sus familiares. Museo también pudo haberse inspirado en otra novela bizantina, las Efesíacas de Jenofonte de Éfeso, en quien halló un inicio de la narración muy similar. En esta novela los amantes se enamoran, también recíprocamente, al encontrarse en un templo no consagrado a Afrodita sino a Artemis. Los dos personajes, Habrócomes y Antia, también se casan de manera bastante inmediata a su encuentro, y su autor incluye un mínimo himeneo al tratar el matrimonio de los dos amantes. Para la descripción en sí del enamoramiento Museo se ha basado también en un conocido pasaje del Fedro de Platón y en otras dos novelas bizantinas que también lo imitan, el Leucipa y Clitofonte de Aquiles Tacio y las Etiópicas de Heliodoro. Es posible q ue haya tomado el motivo de la misma flecha que hiere a los dos amantes del Dafnis y Cloe de Longo ${ }^{19}$.

Museo aduce también una rivalidad política para justificar el matrimonio secreto de sus dos protagonistas. En los versos iniciales, cuando invoca a las diosas, alude directamente a uno de los episodios centrales de su poema, el himeneo celebrado a oscuras la primera noche en la que los amantes consuman su amor. Para ese episodio central de su epilio el gramático griego ha desarrollado algunas de las partes más importantes del género del epitalamio. Al presentar esa primera noche como si fuera realmente la de sus bodas parece haber eliminado detalles del encuentro de los amantes en la playa para concentrarse específicamente en la consumación de su amor en el aposento de la amada. En el transcurso de esa noche alude a los

19. Para las fuentes del opilio de Museo, pueden verse las notas a su traducción casellana del texto por José Guillermo Montes de Cala
(1994) y también el trabajo de Antonio Villarrubia (2000: 365-401). 
diferentes rituales del himeneo que en su mayoría no puede tratar de forma convencional por ser secreto. Entre esos rituales incluye la unción que Hero practica en el cuerpo desnudo de Leandro y la desatadura que lleva a cabo Leandro del cordón que ciñe la cintura de Hero como paso inmediato a la rendición de su virginidad.

Ovidio no se refiere a ningún tipo de himeneo cuando menciona muy de pasada los placeres que los amantes disfrutan todas las noches que se reúnen en el aposento de la torre. Al revés que Museo se demora en la descripción del encuentro de los amantes en el agua. En la primera heroida, Leandro recuerda precisamente a Hero bajando hasta el mar para en su orilla besarlo y secarle los cabellos con su túnica:

Excipis amplexu felicique oscula iungis,

Oscula, di magni, trans mare digna peti,

Eque tuis demptos umeris mihi tradis amictus

Et madidam siccas aequoris imbre comam ${ }^{20}$.

['Me recogías en un abrazo y juntabas nuestras las boquitas sabrosas, besos, ¡oh grandes dioses, dignos de ser buscados al otro lado del mar. Igualmente me das tu túnica que te quitas por los hombros y secas mis cabellos mojados por el agua del mar'].

En la segunda, Hero tampoco puede dejar de evocar ese encuentro dentro del agua en que lo seca utilizando su ropa:

Bracchia nunc umeris umida ferre meis,

Nunc dare, quae soleo, madidis velamina membris ${ }^{21}$.

['Ahora rodeas mis hombros con tus brazos húmedos, ahora te doy, como acostumbro, mis ropas para [secar] tus miembros mojados'].

Museo habría tenido también en su modelo, el mismo que el de Ovidio, la escena del recibimiento de Hero a Leandro en el mar o en la playa, pero ha preferido suprimirla para trasladarla a la parte de arriba de la torre, a la puerta del aposento en el que sitúa el himeneo secreto de los dos amantes. Es en el exterior de ese aposento en el que hace que Hero abrace a Leandro y en el que también menciona el cabello mojado del amante que acaba de cruzar el Helesponto. Después ya los presenta en el interior del aposento para describir la unción que la amada lleva a cabo en el cuerpo de su amante y que llega incluso a comentar en voz alta antes de invitarlo a desfallecer en sus brazos:

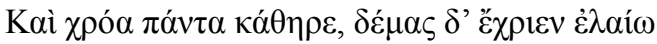

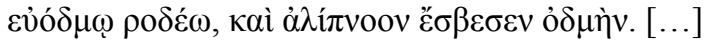

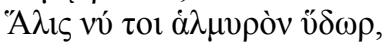

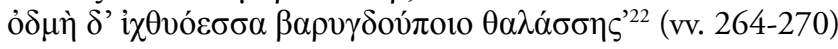

20. Ovidio (I950: 128).

21. Ovidio (I950: 135). 
['Y limpió perfectamente la piel, y además se sirvió para el cuerpo de aceite perfumado de rosa e hizo desparecer el olor marino... basta ahora para ti de agua salada, basta de olor a peces de mar violento'].

Guillermo de Mara, el primer traductor en verso del epilio de Museo, ya a principios del siglo XVI, ofrece una versión bastante literal del texto griego, por más que desde el título la presenta como parafrástica y poética:

Salsamque cutem studiosa retractat

Fragrantique rosam corpus perfundit olivo

Et mare spirantem famulans extinxit odorem [...]

'salse tibi sit satis unda,

Cum maris altisoni nimium piscosus odor $\operatorname{sit}^{23}$.

['y hace desaparecer afanosamente la sal de la piel y rocía su cuerpo con aceite perfumado de rosa y extingue servicialmente el olor que exhala el mar [...] 'basta ya de ondas saladas, basta ya del olor excesivo a peces del mar fragroso']

La unción con aceites perfumados estuvo muy extendida en la antigua Grecia no sólo con finalidades higiénicas (Homero, Odisea, III, 466, VIII, 457, X, 450, y XVII, 88) sino también como una manera de estimular la libido, especialmente entre los esposos, como lo demuestra su uso por Hera para obtener los favores de Zeus, según lo cuenta Homero en la Iliada (XIV, 169-177) y Nono de Panópolis en las Dionisiacas (XXXII, 15-18). En uno de sus poemas, la poetisa Safo menciona la unción con aceites de nardo y jazmín como un afrodisíaco para incentivar el deseo previo al juego erótico (Fr. 94 P, 18-20). Es especialmente con esta función con la que las novias griegas untaban sus propios cuerpos en la noche de bodas (y tal vez los novios hacían otro tanto con los suyos, según se desprende del vocativo empleado por Catulo en uno de sus epitalamios: «unguentate... marite' ['marido... perfumado'], Carmina, 61, 142).

En otras ocasiones el uso de la unción no parece tener un único sentido. Tras convencerlo a compartir su lecho, Circe ordena a una de sus criadas que lave y unja el cuerpo de Ulises (Odisea, X, 362-365 y 450-451). La maga pretende prepararlo en un principio para el amor pero en seguida comprobamos que lo hace para sentarlo a su mesa y ofrecerle sus mejores manjares. Homero deja claro que con el baño (y no con la unción) la sirvienta de turno ha conseguido eliminar el cansancio del cuerpo de Ulises:

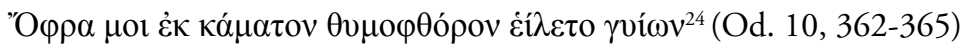

22. Museo (2003: 28).

23. Musaei vetustissimi Poetae Opusculum de amoribus Lenandri et Herus, Guilelmo de Mara paraphraste, eruditis Ioannis Vatelli Coenoliensis commentariis enarratum, París, 1538, fol. [d vj ro]. 
['para quitarme el arrollador cansancio de mis miembros']

Con un propósito más específicamente purificador pudo igualmente practicarse la unción en la Grecia antigua. Es Homero quien también parece mencionarla con ese sentido al menos una vez. Lo hace en el episodio en que Venus es ungida y vestida con sus mejores ropas nada más llegar a su santuario de Pafos después de haber sido sorprendida por su esposo Hefesto en fragrante adulterio con Ares (Odisea, VIII, 3 64-365):

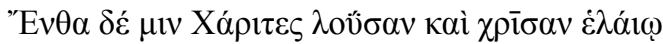

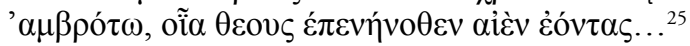

['Allí mismo las Gracias la lavaron y la ungieron con aceite inmortal, como suelen hacerlo los dioses de vida eterna'].

Las Gracias solían formar parte del séquito de Afrodita e incluso una de las tres se la ha llegado a considerar esposa de Hefesto. Como compañeras de la amante de Ares podían representar el encanto y la belleza, que de alguna manera intentarían devolver y restituir a su señora tras su lamentable adulterio. Al untarla con el aceite de los dioses la están preparando y purificando para ser el objeto de culto en el santuario en que la veneran. La propia Afrodita (pero ya en la versión romana) lava y unge el cuerpo de su hijo Eneas para convertirlo precisamente en dios (Ovidio, Metamorfosis, XIV, 600-608).

En la Biblia hay también referencias constantes a la unción porque era costumbre muy establecida por los israelitas. En el Antiguo Testamento, Dios manda a Moisés elaborar un oleo santo con el que ungir a Aarón y a sus hijos para que ejerzan las funciones de su sacerdocio (Éxodo, 30-38); también ordena la unción de quienes ha elegido como reyes (Saúl, David y Salomón en I Samuel 9, 16, 1 Samuel 13, 16, y 1 Reyes 1, 39, respectivamente) y como profetas (Eliseo en 1 Reyes 19, 16). En el Nuevo Testamento, Jesús es ungido por una mujer en los pies o en la cabeza como un gesto de respeto y hospitalidad (Lucas 7, 36-50, Mateo 26, 6-13, Marcos 14, 3-8, y Juan 12, 1-8). La unción de los cadáveres para conservarlos fue practicada no sólo entre israelitas (Marcos 16, 1) sino también entre griegos (Homero, Iliada, XXIV, 585-589, y Bión en el Canto fúnebre por Adonis, vv. 76-78).

Museo, sin duda, podía recordar estas costumbres y usos de la unción cuando la aduce la noche en que sus protagonistas celebran su himeneo secreto: Hero limpia el cuerpo exhausto de Leandro y lo perfuma para quitarle el mal olor del mar, pero no hace lo mismo con el suyo. El gramático griego podía en principio otorgar a la unción, como parte del himeneo, una función afrodisíaca pero tampoco cabe descartar que pensara en esos fines purificadores y diviniza- 
dores que habría aprendido tanto en la literatura clásica como en la bíblica ${ }^{26}$. Es posible que conociera el célebre episodio que Jesús había protagonizado en Galilea y en Betania en casa de Simón el fariseo o de Lázaro al ser ungido por una mujer que le había en un caso incluso secado los pies con sus cabellos tras bañárselos con lágrimas propias (Cristo en griego y Mesías en hebreo significan 'ungido'). Por ese gesto, que interpreta de hospitalidad y también de profecía de su propia muerte, Jesús le perdona a la mujer todos sus pecados y la relaciona directamente con su misión redentora y salvadora. Museo habría convertido a Leandro en otro ungido pensando precisamente en esa misión al permitir que Hero preparara su cuerpo no sólo para el amor sino también para la muerte. Al menos tres poetas posteriores (uno medieval y otros dos renacentistas) acabarán reconociendo en el pasaje esa vinculación con los evangelios al establecer con ellos referencias muy directas, como veremos más abajo.

Antes que Museo Nono de Panópilos ya habría cristianizado uno de los episodios de unción que recordábamos hace un momento. En sus Dionisiacas (XXXII, 15-18) recrea ese episodio en concreto de la Iliada (XIV, 170-178) de Homero del que suprime la parte en que Hera se unge la piel de todo su cuerpo para practicarla en exclusiva en sus cabellos (nuestro gramático, en cambio, conservó la referencia a la unción de la piel de su protagonista para eliminar la alusión al peinado):

Kàı $\pi \lambda \dot{\varepsilon} \kappa \tau \eta \eta v ~ \theta v o ́ \varepsilon v \tau \iota ~ k o ́ \mu \eta v ' ~ \varepsilon \delta i ́ \eta v \varepsilon v ~ \varepsilon ̇ \lambda a i ́ \omega ~(v . ~ 16)^{27}$.

['Y se mojó con un aceite perfumado sus trenzados cabellos'].

Homero, en cambio, había concedido mucha mas atención al cuerpo de la esposa de Zeus que a sus cabellos, que menciona al final del episodio para decir que más que ungirlos lo que hizo la diosa fue peinárselos:

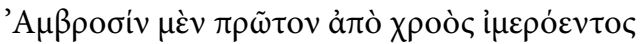

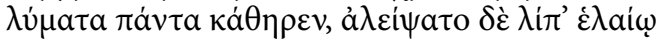

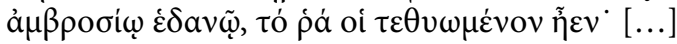

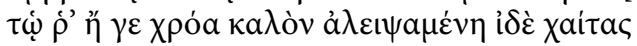

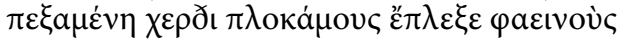

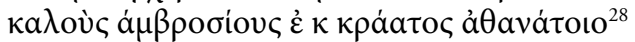

['Primero purificó con ambrosía todas las impurezas de la deseable piel y se ungió con untuoso aceite, ambrosiaco y perfumado, que ya estaba aromatizado para ella [...] Con él [el aceite] se ungió su hermosa piel y también peinó sus cabellos trenzando con sus manos los bellos y brillantes rizos de ambrosía que caían desde su cabeza inmortal'].

otros libros del Nuevo Testamento.

27. Nonos de Panopolis (1997: 102).

28. Homero (2009: 159-160). 
Es verosímil que para esa supresión que efectúa del poema homérico Nono de Panópolis, que se había convertido al cristianismo y había escrito la Paráfrasis del evangelio de san Juan, se hubiera inspirado en una escena similar (pero nunca idéntica) en que algunos evangelistas (entre ellos también san Juan) narran la unción sólo de los cabellos de Jesús por una mujer que no siempre identifican. Más abajo analizaremos todas las versiones de esta escena evangélica para justificar los cambios que tanto Bernardo Tasso como Juan Boscán introducen en sus respectivas interpretaciones de la fábula.

En el transcurso de esa escena Nono de Panopolis aprovecha la ocasión también para exaltar la institución del matrimonio utilizando como portavoz a su patrona, precisamente la diosa Hera. En las novelas bizantinas en las que Museo ha podido inspirarse para convertir en esposos clandestinos a nuestros personajes no hay una defensa tan contundente ni manifiesta de una institución que en la Edad Media (al menos en literatura) sufrió un desprestigio que humanistas como Leoón Battista Alberti y Giovanni Pontano intentaron subsanar. Nono pone en boca de Hera un elogio del matrimonio cuando la diosa se dispone e renovar su himeneo con Zeus vistiendo el mismo variegado ropaje que aún conserva la mancha de la sangre derramada en la primera unión con su esposo:

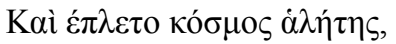

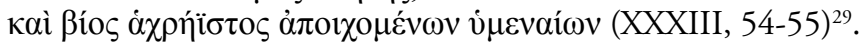

['Y el universo avanza extraviado y la vida se ha vuelto inútil desde que se han alejado los himeneos'].

Nono ya se había pronunciado en estos términos en cantos anteriores para defender una institución que era la insignia del cristianismo (XXIV, 266). En ese contexto, en que siempre se le ha situado, Museo podía haber asumido ese papel moralizador que le hemos asignado al cambiar posiblemente el estado civil de nuestros dos amantes: si no recordamos mal es de los primeros autores en proponer para personajes de ficción el matrimonio secreto sin más testigos para hacerlo válido que los propios esposos que han dado su consentimiento.

Es difícil saber, por otro lado, si la escena de la unción como parte del himeneo se la inventa Museo o la toma del poema alejandrino que ha usado para componer su epilio. En la segunda heroida Ovidio alude también a la unción del cuerpo de Leandro pero no en el lecho de Hero sino en la playa antes de iniciar su travesía por el mar cuando ya se ha despojado de su túnica:

Iamne suas umeris illum deponere vestes,

Pallade iam pingui tinguere membra putas? ${ }^{30}$ 
[‘Crees que en este momento él deja caer de sus hombros sus vestidos y ya se ha ungido los miembros con el óleo de Palas?’].

Esta unción que Hero imagina en su amante parece la propia que atletas y luchadores practican en los gimnasios para otorgar con el aceite agilidad a sus cuerpos antes de iniciar las actividades deportivas. No creo que deba ponerse en relación con la que la propia Hero practica a Leandro cuando lo sube a su aposento porque difícilmente podremos interpretar la travesía de nuestro nadador como un baño convencional (la unción purificaba antes y después del baño). Pero Ovidio no ofrece demasiados detalles sobre los placeres que sus personajes se dispensaron la primera noche de su encuentro. Entre esos placeres que decide que los dos amantes callen podría estar pensando -pero tampoco es seguro que lo hiciera- en la unción de sus cuerpos (el de uno solo o de los dos) con una evidente función afrodisíaca y purificadora.

Museo (y antes Ovidio) identifica el fuego de la lámpara que cada noche enciende Hero para guiar en la oscuridad a Leandro con el amor que prende en su corazón y que le permite con su calor atravesar las frías aguas del Helesponto. Está claro que los dos autores toman este motivo (muy habitual en la lírica) del poema helenístico hoy perdido. Es de ese modo que al narrar el ahogamiento de Leandro el gramático griego deja muy claro (también lo hace en parte Ovidio en la primera de sus heroidas) que el viento que apagó la famosa lámpara también extinguió la vida y el amor de nuestro nadador:

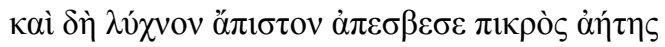

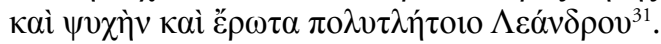

['Y en ese instante un cruel viento apagó la pérfida lámpara y la vida y el amor del sufridor Leandro'].

Museo ha revestido el amor de sus dos personajes de un barniz conyugal que no ha sabido diferenciar de un amor más espiritual y menos carnal. Por ese segundo componente ha considerado el amor de sus protagonistas tan breve como sus propias vidas. Es un componente que ha heredado de la interpretación más antigua de la fábula y que ha intentado suplantar por otra más honesta. Es precisamente esa interpretación la que acabará prevaleciendo en los autores posteriores, especialmente los contemporáneos o muy poco posteriores a Museo, que debieron de haber conocido su epilio. Los autores medievales, recuperando no se sabe cómo la tradición alejandrina, poco a poco fueron combatiéndola para adaptarla a su versión más cristiana de las distintas regiones del Hades en las que suponen a los amantes (unos más castigados pero también otros bastante menos) perpetuando su amor más allá de la muerte.

31. Museo (2003: 33). 


\section{La fábula en la Edad Media}

Los mitógrafos griegos antiguos (Paléfato, Heráclito, Eratóstenes, etc) no llegaron a tratar la fábula de Leandro y Hero por no estar aún creada en los siglos en que escribieron sus obras. Es posible que circulara como leyenda bastante antes de la redacción de las Geórgicas de Virgilio. Se ha fijado para su formación un amplio período que comprende el año 280 a. de C. hasta el I d. de C.

El gramático Servio (de finales del s. IV d. de C.) comenta los versos citados de las Geórgicas dando una información que sólo puede haber tomado del poema alejandrino perdido al que, como hemos dicho ya, se remontan las dos versiones más cabales de la historia. Servio deja claro que Hero se quita la vida arrojándose al mar desde una torre cuando de los versos de Virgilio que comenta sólo ha podido saber que la muchacha acaba muriendo:

... nec miseri possunt revocare parentes,

Nec moritura super crudeli funere virgo (III, 272-273) ${ }^{32}$.

('... ni los desgraciados padres ni la doncella que morirá de cruel muerte se lo podrán impedir').

El comentarista latino, además de aportar el dato importantísimo sobre el tipo de suicidio de Hero, insiste en la moralización virgiliana al considerar que el amor de los hombres es más duro que el de los animales. Acaba su escolio diciendo que Virgilio ocultó el nombre de los amantes por pensar que la fábula estaba ya entonces muy difundida:

Quid iuvenis ne forte occurreret, illa animalia carere ratione, dicit etiam homines gravius in amore moveri. fabula talis est: Leander et Hero [...] fuerunt invicem se amantes. sed Leander natatu ad Hero ire consueverat per fretum Hellesponticum, quod Seston et Abydon civitates interfluit. cum igitur iuvenis oppressi tempestate cadaver ad puellam delatum fuisset, illa se praecipitavit e turri. et aliter: Leandri nomen occultavit, quia cognita erat fibula ${ }^{33}$.

('Porque el joven no fue arrastrado por casualidad, al carecer los animales de razón, [Virgilio] dice que los hombres también son conmovidos más poderosamente por amor. La fábula es de este modo: Leandro y Hero [...] fueron amantes recíprocos pero Leandro solía ir nadando hacia Hero a través del estrecho de Helesponto, que separa las ciudades de Sesto y Abidos. Cuando el cadáver ahogado del joven fue descubierto por la muchacha, ésta se precipitó desde la torre [...] [Virgilio] ocultó el nombre de Leandro, porque era fábula conocida’)

Fulgencio fue el primer autor entre los especialistas en el género de las fábulas en rescatar la de Leandro y proponer una lectura más allá de la literal en sus 
Mythologiae libri tres, compuestos en el siglo v o principios del vi d. de C. Fulgencio no sigue la misma línea de interpretación que Virgilio porque considera el mar como la fría vejez en la que se acaba extinguiendo la lujuria. Al igual que el poeta latino, entiende que los amores de Leandro y Hero son especialmente carnales y físicos, pero por eso mismo los considera muy efímeros, porque piensa que dura lo que la juventud:

Amor cum periculo sepe concordat et dum ad illud solum notat quod diligit, numquam uidet quod expedit. Eros enim Grece amor dicitur, Leandrum uero dici uoluerunt quasi lisinandron, id est solutionem uirorum; solutio enim uiri amorem parturit. Sed natat nocte, id est: in obscuro temptat pericula. Ero quoque in amoris similitudine fingitur. Lucernam fert; et quid aliud amor nisi et flammam ferat et desideranti periculosam uiam ostendat. Cito tamen extinguitur, quia iuuenilis amor non diu perdurat. Denique nudus natat illa uidelicet causa, quod suos affectatores amor et nudare nouerit et periculis sicut in maris iactare. Nam et extincta lucerna utrisque mors est procurata maritima, hoc in euidenti significans quod in utroque sexu uapore aetatis extincto libido commoritur. In mari uero mortui feruntur uelut in humorem frigidae senectutis; omne enim caloratae iuuentutis igniculum torpidae ueternositatis algescit in senio (Mit., III, 4$)^{34}$.

('Amor a menudo concuerda con el peligro y mientras el amor sólo se da cuenta de lo que desea, nunca ve lo que le conviene. Amor se llama en griego Eros, y pretenden decir Leandro como lisinadron, esto es, soltura de varones; la soltura sin duda engendra el amor del varón. Pero nada de noche, esto es, acomete los peligros en lo oscuro. Eros también se toma de la semejanza de amor. [Hero] trae una lámpara, y que no es amor sino el que trae la llama y muestra la vía peligrosa al que desea. Pronto [la llama] se apaga, porque el amor juvenil no dura mucho tiempo. Por último nada desnudo por esta causa, a saber, que el amor sabe desnudar a los que desean y arrojar a los peligros como al mar. Pues apagada la lámpara se produce la muerte marítima de ambos, significando esto de manera manifiesta que en uno y otro sexo, habiéndose apagado el vapor de la edad, se consume la lujuria. Pero son arrojados muertos al mar como al humor de la fría vejez; todo pequeńo fuego del ardor de la juventud se enfría en la vejez de la somnolencia indolente').

Los tres autores del texto conocido como Mitógrafos Vaticanos I, II y III por haberse conservado el más completo en un manuscrito de la Biblioteca Vaticana también recogen la fábula de Leandro y aportan unas breves interpretaciones alegóricas. El primero de los tres autores, cuyo texto original se ha fechado entre el último cuarto del siglo ix y el tercer cuarto del XI, narra la historia de la fábula para al final proponer una lectura menos literal. Empieza mencionando las ciudades en las que viven los protagonistas, de quienes destaca su hermosura, para indicar que las dos están separadas por el mar. Narra la muerte de los dos amantes: la de Leandro intentando cruzar el mar y la de Hero cayéndose desde

34. Fabius Planciadius Fulgentius (1970). 
un lugar elevado (pero no demasiado especificado); y cierra el capítulo con un comentario moral sobre los placeres mundanos como la causa del final trágico:

Sextus et Abydus urbes vicinae erant, et interfluentes maris arto divisae. Una earum celebris extitit per Leandrum, pulcherrimum iuvenum; altera per Hero, pulcherrimam mulierem; quibus absentibus, amor imis concaluit mentibus. Juvenis autem, impatiens ignis, omni modo quaerebat obtinendae virginis copiam. Sed nullo ad Hero terra aditu invento, simul calore et audacia impulsus, se ponto tradidit [...] Cujus corpus quum postero die ejectum in litore fluctibus Hero vidisset, dolore instincta a culmine cecidit. Sic cum quo sortita fuit partem mundanae voluptatis, cum eo et pertulit damnum mortiferae acerbitatis (Myth. Vat., I, 28) ${ }^{35}$.

('Sexto y Abidos eran ciudades vecinas, y separadas por un estrecho de mar. Una era famosa gracias a Leandro, joven bellísimo, y la otra gracias a Hero, muchacha bellísima. Estando ausentes, un amor profundo calentó por completo sus corazones. Pero el joven, no pudiendo dominar el fuego, buscó la manera de conseguir el tesoro de la virgen. Pero al no hallar por tierra ningún acceso a Hero, impulsado por el ardor y la audacia al mismo tiempo, se entregó al mar [...] Cuyo cuerpo [el de Leandro] fue arrojado al día siguiente por las olas a la playa. Al verlo, Hero, instigada por el dolor, se cayó del techo. Así cuanto más hubo salido la parte del placer mundano tanto más se cumplió el daño de la desgracia mortífera')

Es muy interesante la mención que hace al principio de las ciudades en relación con la belleza de los jóvenes que las habitaban porque podría indicar que el autor del mitógrafo vaticano I llegó a conocer directamente el poema alejandrino, hoy perdido, al que remontan las versiones más conocidas. Es una referencia que también da Museo (y solo él) en los primeros versos de su epilio:

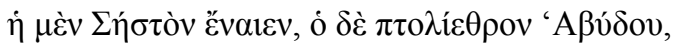

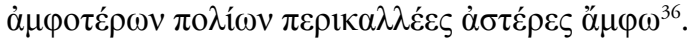

['Ella en verdad habitaba en Sestos, él por otro lado en la ciudad de Abidos, los dos hermosísimas estrellas de sendas ciudades'].

El Mitógrafo II, conservado en otros diez manuscritos, aparte el común de la biblioteca vaticana, sigue literalmente el I, del que copia buena parte de la sinopsis e integra la interpretación alegórica. Añade al principio una visión general de la fábula tomada del escolio de Servio:

Leander Abydenus et Hero Sestias fuerunt invicem se amantes. Sed Leander natatu ad Heron ire consueverat per fretum Hellespontium, quod Seston et Abydon civitates interfluit. Extincta autem casu face, quam Hero statuto tempore praetendere solebat... (Myth. Vat., I, 28) ${ }^{37}$. 
('Leandro abideno y Hero sestias fueron amantes que se correspondieron. Pero Leandro acostumbraba a ir nadando a través del estrecho del Helesponto, que separaba las ciudades de Abidos y Sesto. Apagada por casualidad la antorcha que Hero a una hora fijada solía mostrar...')

En otros de los manuscritos que ha transmitido el texto del Mitógrafo II se ofrece una versión del suicidio de Hero más próxima a la de Servio:

Extincta autem casu face $[\ldots]$ juvenis tempestate periit. Cujus corpus quum ad puellam delatum fuisset, ipsa se praecipitavit in mare» (Myth. Vat., II, 218)

('Pero apagada la antorcha por casualidad [...] el joven pereció a causa de la tempestad. Cuyo cuerpo [el de Leandro], cuando fue mostrado a la muchacha, ella misma se precipitó al mar').

A finales del siglo XI, el francés Baldric de Bourgueil, perteneciente a la famosa escuela de poetas latinos de Loira, escribió un poema (el 254 de sus Carmina) sobre la fábula basado en las dos heroidas de Ovidio. En su desenlace aporta un detalle nuevo y muy significativo para la salvación de sus protagonistas. Presenta a Hero derramando lágrimas sobre el cuerpo de Leandro y secándoselas con sus cabellos:

Irruit et laceris artubus inicitur;

Infundit lacrimis iuvenem siccatque capillis ${ }^{38}$.

['Se arrojó y abalanzó sobre los miembros destrozados; inunda con sus lágrimas al joven y se las seca con sus cabellos'].

Para esa acción que atribuye a su heroína Baldric se ha basado en la escena bíblica de la mujer pecadora que en casa de Simón el fariseo baña con sus lágrimas los pies de Jesucristo y se los seca con sus cabellos (Lucas, 7, 36-50). Por ese gesto de hospitalidad Jesús le perdona todos los pecados y le hace saber que su fe la ha salvado. Si el autor francés ha añadido el detalle de los cabellos es porque de algún modo pretende salvar a sus personajes en el instante de sus respectivas muertes.

Después de narrar la muerte de Hero, para la que se ha inspirado en la primera de las dos heroidas de Ovidio, el poeta francés incluye unos versos en los que aporta una moraleja o interpretación que en parte (y solo en parte) toma de Fulgencio. Aprovecha la ocasión para cuestionar la verosimilitud de la historia:

Hic consummavit, si creditur, exitus ambos

Castigans hos qui non sapienter amant.

37. Scriptores rerum mythicarum latini tres Romae nuper reperti, ed. cit.
38. Baldricus Burgulianus/ Baudri de Bourgueil (2002: 97). El editor señala la reminis- 
Res impossibilis, sapiens quam Grecia finxit,

Te movet ad sensum, qui legis hec, alium.

Est «resolutus homo» per consona dicta Leander

Vel que dissoluit res fluidos homines;

Et resolutus homo subito consentit amori

Et natat in mundo iam velut in pielago.

Nam furibundus amor postquam distemperat artus,

In mare fluctivagum nocte trahit miserum ${ }^{39}$.

['Aquí se consumó la muerte de ambos, si es que se cree la historia, reprendiendo a estos que no aman con sensatez. El suceso imposible, que un sabio griego inventó, te mueve a que lo leas en otro sentido. Se ha dicho Leandro por el «hombre disuelto', o por lo que destruye a los hombres inconstantes; y el hombre disuelto de repente cede al amor y nada en el mundo como en el mar. Pues un amor furibundo después destempla el cuerpo y arrastra al desventurado de noche a vagar por entre las olas del mar'].

Borgueil debió conocer de algún modo la tradición alejandrina de la fábula porque se refiere muy explícitamente, al igual que Antípatro de Sidonia, a la sepultura que comparten los dos amantes pero en el mar al que se arroja Hero tras besar mil veces el cadáver de su amante:

«Obsecro vos, venti, flatus coniungite nostros;

Corpora iuncta simul tu, mare, suspicias»;

Dixit et astrictum post oscula mille cadáver

Seque simul virgo proripit in pelagus ${ }^{40}$.

['Os conjuro, vientos, unid nuestros alientos; acoge tú, mar, a la vez nuestros cuerpos juntos'; dijo la doncella y estrechando el cadáver después de darle mil besos se precipitó con él al mar'].

Ya en pleno siglo XII, el Mitógrafo III, cuyo texto se ha atribuido a diferentes autores (Alberico, Leoncio, Alexander), se desmarca de los dos mitógrafos anteriores al haber usado en parte las interpretaciones alegóricas de Fulgencio:

Ad hujus figuram fabula respicit de Hero et Leandro conficta. Hero enim amor, Leander virorum solutio interpretatur. Amavit igitur juvenis Leander Heron puellam transmarinam. Ad quam quum de nocte nataret, illa in terra contra stans, ne a suo litore aberraret, lampadem ei accendebat. Quadam nocte orta tempestate extinctaque lucerna, juvenis submersus est. Cujus corpus ubi virgo vidit ejectum, se quoque in mare praecipitem dedit. Leander igitur, id est virorum solutio, per virtutis derelictionem et ignaviae indulgentiam Heron amat, id est in amorem et libidinem incurrit. Sed libidine quilibet succensus, dum ad id tendit, quod ardenter diligit,

39. Baldricus Burgulianus/ Baudri de Bourgueil (2002: 97).
40. Baldricus Burgulianus/ Baudri de Bourgueil (2002: 97). 
numquam sane videt quod expedit. Nam et nocte natat, id est in obscura pericula tentat. Hero ei lucernam, ne aberret, accendit. Et quid aliud amor nisi ardorem importat, et desideranti viam periculosam ostendit? Lucerna autem statim extinguitur, quia juvenilis amoris ardor non diu perseverat. Denique et nudus natat, ea videlicet de causa, quod amoris illecebra affectatores suos a substantia et consilio nudare consuevit et in pericula, sicut in mare, jactare. Quod autem lucerna extincta utrique causa mortis est, juxta Fulgentium evidenter significat, quod in utroque sexu libido commoritur. Denique in mari ambo moriuntur, id est, in senectute inquietationis libidinum obliviscuntur. Senectus enim quod frigida et humorosa sit, mari comparabilis videtur. Nam et tempestas, qua periit, possessionis distractionem designat; cujus consideratio libidinis incendium saepissime enecat (Myth. Vat., III, 11, 19).

('Hero significa amor y Leandro soltura de varones. El joven Leandro, pues, amaba a la muchacha de ultramar. A la que cuando de noche nadaba ella estando enfrente en tierra, para que no se apartara de la costa, le encendía una lámpara. Una noche, habiendo empezado una tormenta y apagándose la luz, el joven fue anegado por las aguas. Cuyo cuerpo cuando Hero vio arrojado también se arrojó al mar. Leandro, pues, la soltura de los varones, ama a Hero por la falta de virtud y la complacencia de la apatía, esto es, cae en el amor y la lujuria. Pero cualquiera, encendido en la lujuria, mientras se encamina hacia esta, a la que desea ardientemente, nunca ve completamente lo que le conviene. Porque nada de noche, esto es, prueba los peligros en lo oscuro. Hero le encendió la lámpara para que no se apartara. Y ¿qué otra cosa es amor sino lo que acarrea ardor y muestra la vía peligrosa al que desea? La luz sin embargo se apaga enseguida, porque el ardor del amor juvenil no dura mucho tiempo. Finalmente, nada desnudo, es por esta causa que suele desnudar a sus seguidores por los halagos de razón y de hacienda y arrojar a los peligros así como al mar. Que la luz se haya apagado es la causa de la muerte de los dos amantes, como interpreta Fulgencio, puesto que muere la lujuria de uno y otro sexo. Por último los dos amantes mueren en el mar, esto es, olvidan en la vejez la inquietud de la lujuria. La vejez, que es sin duda fría y húmeda, parece comparable al mar. Pues la tormenta, por cuya causa muere el joven, designa el apartamiento del goce, cuya consideración muy a menudo mata el incendio de la lujuria').

Alfonso X el sabio tradujo bastantes heroidas de Ovidio (pero no todas) e incluyó la mayoría en la segunda parte de su General Estoria, dejando dos para la tercera. No siempre ofreció una versión puntual de las que eligió para su libro, sino que en ocasiones se limitó a dar una sinopsis del contenido no siempre inspirada por las heroidas que aduce como fuente. Es lo que hace, por ejemplo, con las dos nuestras (la XVIII y la XIX) cuando las inserta para resumirlas a modo de glosa en la quinta parte de la General Estoria aprovechando la referencia que Lucano introduce al Helesponto en su Farsalia (IX, 950-956).

El rey proporciona una información sobre la fábula que no puede haber obtenido del texto que menciona porque no aparece en ninguna de las dos heroidas de Ovidio. Para el suicidio de Hero, por ejemplo, debió de aprovecharse de la versión que Servio, siguiendo el poema alejandrino perdido, incluyó en su nota a las Geór- 
gicas. Para la muerte de Leandro tampoco se basa en las heroidas ovidianas porque suministra una versión que no he conseguido documentar en ninguna otra parte:

E acaeció una noche que tardó mucho Leandro e adormiose Ero e menguó la lumbre en la torre tanto, que después Leandro fue en la mar non la veyé, e perdió el siesto de la torre e andido errado por la mar tanto que se levantaron las aguas e cansárosle e murió $y^{41}$.

Para ese trágico final de nuestro amante Irene Salvo ha propuesto como modelo más probable unos epígrafes medievales que encabezando las heroidas en cuestión han sido transmitidos por el códice clm 19475:

Amore immoderato succensus medium mare inter utremque civitatem transnabat [...] Se dum forte ab incepto itinere per septimanam maris inquietacione teneretur, facit hanc epistulam in quo causam morae ostendo se ab ipsa abesse tamdiu conquieretur et doloris causa huius Leandri prima noctis in qua convenerunt reminiscitur quia causa huius puellae, cum quadam nocte transnare vellet, face superextincta, undis obrutus periit ${ }^{42}$.

['Inflamado por un amor inmoderado cruzaba a nado el mar en medio de una y otra ciudad [...] Mientras era retenido ya durante una semana sin poder emprender el viaje por la turbulencia del mar, hizo esta epístola en que mostrando las causa de su demora se lamenta de haber estado tanto tiempo alejado de ella y a causa de su dolor recuerda la primera noche en que se encontraron porque por esta muchacha cuando una noche quiso cruzar a nado [el mar], habiéndose apagado completamente la antorcha, pereció sumergido por las olas'].

Ni Museo ni Ovidio (ni otros textos) presentan a Hero durmiéndose por haberse retrasado su amante. El autor del epígrafe, siguiendo la primera heroida, explica que Leandro lleva una semana demorándose sin poder emprender su viaje por culpa del estado del mar, pero después deja claro que el muchacho a causa de su amada, y por haberse apagado la antorcha, muere ahogado por la fuerza de las olas. La relación que establece entre la muerte de Leandro y el apagamiento de la antorcha que enciende Hero el anónimo autor no la ha podido tomar directamente del texto que comenta porque Ovidio no la determina en ningún momento al no incluir más que por muy vagas indicaciones el trágico final de los amantes ${ }^{43}$.

Alfonso X tampoco llega a establecer esa misma relación porque si bien aduce como causa de la muerte de Leandro la falta de lumbre no la justifica porque

41. Alfonso X el Sabio (2009: 353).

42. Irene Salvo García es la única que ha estudiado esos resúmenes, que considera como integrantes de una glosa a los versos de Lucano, primero en (2012: 569-571), y después en un trabajo fundamental (2012: 875-885). Debo a la amabilidad y gentileza de la autora el haber podido leer las páginas indicadas de su tesis doctoral. 43. Hero nota el chisporroteo de su antorcha mientras está escribiendo la carta a Leandro y lo interpreta como una señal de buen presagio (vv. 151-153). 
la haya apagado el viento sino porque Hero o no la ha encendido al haberse quedado dormida esperando a su amante o después de haberla encendido ha dejado consumirla al no haberse mantenido despierta. Nuestro rey podía haber interpretado mal los epígrafes de su modelo al entender la palabra "uinius» (o «vinius») con el sentido de 'vino' (la oración en que aparece exigiría el genitivo «vini» o «vinii»): habría atribuido a la somnolencia (o mejor a la vinolencia) de Hero la causa del ahogamiento de su amante (y sobre esa versión habría improvisado otra menos indecorosa para la protagonista al suponerla simplemente dormida por la demora de Leandro). La palabra en cuestión, si no es un error por «Bidus» o «Abidus» (véase abajo n.), podría serlo más obviamente por «huius», copiada ya en el caso que pide el contexto.

El rey castellano seguramente habría manejado una versión de la fábula contaminada ya con la de Céix y Alcione porque habría tomado de la segunda la escena en que presenta a Hero dormida en su torre mientras espera a Leandro. En esa fábula Alcione se duerme tras producirse la muerte de Céix (en idénticas circunstancias que la de Leandro) y contempla en sueños el espectro de su marido que le hace saber que ha muerto en el mar. Al despertar la fiel esposa no puede reprimir el dolor que expresa en todas sus formas y ya al amanecer se dirige a la playa en la que embarcó Céix cuando emprendió su viaje. Alcione fija toda su atención en el mar y a lo lejos divisa un cuerpo que en un principio no llega a reconocer pero que después puede identificar sin riego de equivocarse como el de su marido ya sin vida.

En el Ovide moralisé, por ejemplo, obra de la que hablaremos enseguida, su anónimo autor recrea las dos heroidas por el mismo orden que en su modelo. Para completar la fábula añade un principio y un final que parece reconstruir a partir de alusiones contenidas en esas dos heroidas y también de alguna escena tomada de la fábula de Céix y Alcíone. Por el principio no incluye la escena del enamoramiento de los protagonistas porque no da la sensación de manejar ninguna fuente relacionada más o menos directamente con el epilio de Museo.

Para la narración de la muerte de Leandro el poeta francés ha elegido la heroida de Hero a Leandro. En Ovidio la acción de esa heroida transcurre en una de las muchas noches en que los amantes no han podido reunirse en Sestos por el mal estado del mar. El poeta francés convierte esa noche en la noche en que Leandro muere por intentar cruzarlo en condiciones tan precarias. Empieza presentando a Hero quejosa por la tardanza del amante, pero no deja claro si lo está porque su amante lleva siete días sin visitarla (es de lo que nuestra heroína se queja en su heroida) o porque se ha retrasado esa última noche en que espera su llegada. Unos cuantos versos después la describe durmiéndose como consecuencia de los malos presentimientos que la muchacha tiene al contemplar el mar. En sueńos Hero no contempla la sombra de su amante sino la de un delfín expulsado ya sin vida por el mar a la costa. Al despertarse desciende de la torre y en la playa reconoce el cuerpo muerto de Leandro. Se abalanza sobre su cadáver para besarlo y abrazarlo hasta morir de dolor sin despegarse en ningún momento de su amante. 
Para el sueño de Hero el anónimo autor del texto francés no ha hecho más que adaptar la parte final de la segunda heroida ovidiana. En esos últimos versos la muchacha explica que la noche anterior se había dormido y había visto en sueños a un delfín arrojado ya sin vida por las olas a la playa tras nadar en medio de un temporal marítimo. Nuestra heroína interpreta el sueño como un mal augurio y aconseja a su amante no emprender la travesía por el Helesponto hasta que sus aguas no se hayan calmado. Al principio de la heroida Hero también se había quejado de la tardanza de Leandro y la había atribuido a la existencia de una rival que lo habría entretenido en otro lugar.

Si el autor francés ha decidido incluir ese sueño de Hero como inmediatamente anterior a su propia muerte y a la de su amante es porque había leído otra muy similar en la fábula de Céix y Alcíone que también anticipaba el mismo trágico final de los amantes. El poeta francés otorga al sueño el valor de presagio que Hero interpreta de idéntica manera que Alcione al dirigirse nada más despertar a la playa para comprobar que efectivamente se ha cumplido. El autor del Ovide moralisé tampoco alude para nada a la famosa antorcha porque no le atribuye el papel fundamental que Museo le da en su versión de la fábula.

Alfonso X parece haber utilizado si no el modelo del poema francés al menos uno muy parecido porque ha unido también la escena del sueño con la del desenlace de la fábula. En su afán por abreviarla (al tratarse de una simple glosa a su traducción de la Farsalia de Lucano) ha situado a una misma altura los lamentos de la protagonista por la tardanza de su amante y el sueño que se apodera de ella mientras lo está esperando. Para que las semejanzas con el poema francés fueran totales el rey debería haber reproducido el sueño profético de Hero. Si no lo hace es porque posiblemente esté pensando en la brevedad de su glosa o también porque ya se hubiera eliminado en su modelo. Tampoco menciona para nada la aparición del cadáver de Leandro en la playa de Sestos y da como la causa del suicidio de Hero su mera sospecha de que su amante ha muerto en el mar por no haberse llegado en toda la noche.

Nuestro rey sabio tiene en mente las dos heroidas porque recuerda especialmente los recibimientos de Hero a Leandro en la playa de su torre (se limita a constatarlos sin ofrecer más detalles al respecto):

E ella estaba siempre al pie de la torre presta para recibirle, e desque llegaba a él acogiense a la torre a furto e en gran poridat e d'esta guisa avién su amor ${ }^{44}$.

Cuando por boca de sus personajes narra esos encuentros Ovidio solo se refiere una vez a la "turris conscia» ['torre cómplice'] (XVIII, 195), pero nunca menciona su "pie», la parte de la playa, situada frente a ella, en la que Hero espera a su amante. El único autor que lo hace muy explícitamente es Museo cuando describe el lugar en el que la muchacha ha visto el cadáver de Leandro (vv. 338-339). En la

44. Alfonso X el Sabio (2009: 353). 
Edad Media no conozco ningún otro texto en que haya alusiones «al pie de la torre», y sólo he podido documentarlas a partir de mediados del siglo Xv (véase n.).

A pesar de tratarse de una digresión meramente informativa, el rey sugiere una breve alegoría (no moralización) de la fábula al atribuir a sus componentes más importantes (incluidos los personajes) un sentido similar (pero nunca idéntico) al propuesto por autores posteriores:

E llamaron por ende a aquel logar el mar de los amores, et al alcázar de Ero las torres de la ribera de la lágrimas, por Ero que lloraba allí mucho primero e se mató después ${ }^{45}$.

Para el pasaje el rey sabio se ha limitado a traducir los versos en que Lucano presenta el escenario donde transcurrió nuestra fábula otorgándoles un sentido a cada uno de sus lugares (especialmente el mar y las torres):

Et amore notatum

Aequor et Heroas lacrimoso litore turres,

Qua pelago nomen Nephaleias abstulit Helle ${ }^{46}$.

['y se ha de indicar el mar por el amor y las torres de Hero por la costa lacrimosa, por cuyo piélago el nombre obtuvo de Hele, la hija de Nefalia’].

El anónimo autor del Ovide moralisé, ya a principios del siglo xIv, dedica casi setecientos versos a nuestra fábula para completar la de la ninfa Hele, ahogada en el Helesponto (de ahí el nombre de este estrecho de mar). Divide su exposición en dos partes: una histórica en que ofrece una narración completa y literal de la fábula, basada en las dos heroidas de Ovidio, y otra alegórica en que propone dos interpretaciones del relato completamente antagónicas.

En la parte histórica, el poeta francés introduce, como hemos ya visto, pequeños detalles que toma de otra fábula, la de Céix y Alcíone, cuyo desenlace es muy parecido (Céix muere ahogado y Alcíone intenta suicidarse arrojándose al mar sobre el cadáver de su esposo), e inicia de este modo una contaminación entre las dos fábulas que autores posteriores llegaran a ampliar (Nadal, Corella, Tasso y Boscán). Es el primero, por ejemplo, en incluir el sueño de Hero como presagio de la muerte de Leandro, pero para el sueño se inspira básicamente en el final de la segunda heroida ovidiana (aunque en casos puntuales parece mezclarlo con el de Alcione).

En la segunda parte nuestro misterioso autor recuerda al principio la interpretación o moralización (la llama «alegoría») más aceptada y difundida de la fábula en la Edad Media al identificar al protagonista como el prototipo del lujurioso y al lugar en el que ha nacido la protagonista (especifica sobre el mar porque tiene presente que de sus espumas había nacido Venus) como la parte más lujuriosa del cuerpo femenino: 
D'ome qui met s'entencion

En fole amour, en fole arsure,

Amoit Hero, ce fu luxure,

Qui fu nee en Sexte sur mer,

Quar toute la force d'amer,

Toute la cause et la nature,

Toute femenile luxure

Naist en Sexte, membre de femme ${ }^{47}$.

Pero a continuación expone la moralización contraria al presentar a Hero, ya no como la incitadora de la lujuria, sino como encarnación de la sabiduría divina y a Leandro, ya no como lujurioso, sino como el representante del linaje humano que pretende adquirirla para alcanzar la morada celestial transitando cada noche por el mar de la vida. Si, como acabamos de ver, entiende que Sestos es el paraíso, piensa que Abidos no puede ser más que el mundo en que ha nacido el hombre Leandro y el mar la vida mortal que ha de recorrer para llegar a la meta que se ha propuesto desde la cuna:

Par Hero puis pendre et gloser

Cete divine sapiente

Qui tout afine e tout commence

Et tout ordene soëfment.

Par Leandre puis droitement

Entendre home ou humain lignage.

Par Sexte le hault herbegage

Des cieulx; par Abydos le monde.

Par le mer estroite et parfonde

Puis noter cete mortel vie ${ }^{48}$.

De acuerdo con este planteamiento sugiere a continuación una explicación de la muerte de los dos amantes que tiene por objeto principal la redención del uno gracias a la intercesión del otro. Leandro no logra el propósito de conseguir la sabiduría divina porque al intentarlo ha sucumbido ante al mar de los pecados (inherentes a la vida humana) y se ha hundido en el infierno. Hero, personificación de la sabiduría divina, desciende de su torre, implícitamente identificada con el paraíso, para rescatar, como si fuera Jesucristo, a Leandro del infierno y llevarlo al alto cielo:

Et, pour plus doubler ses anuis,

Il ne pooit ne jour ne nuis,

C'est a dire ne mors ne vis,

Ataindre au port de paradis,

Quar la tormente de pechié

Et son pasaje empechié [...]

48. C. de Boer (1966: 88-89). 
Lors perdi homs la droite voie, Si le fist pechiez forvoier.

Ce le fist perir et noier

Au flos d'enfer, sans alegance,

Mes la devine sapiance,

Qui mise ot en lui s'amistié,

Pour home raembre et requerre,

Voult descendre dou ciel a terre

Et prendre en fame char humaine

Et soi livrer a mortel paine

Pour home, que tant pot amer,

Si le trait de l'amere mer

D'enfer au saluable port

Plain de perdurable deport ${ }^{49}$.

En su obra maestra, la Divina Commedia, que compone también a principios del siglo XIV, Dante no incluye ni a Leandro ni a Hero entre los amantes lujuriosos que pueblan el segundo círculo de su infierno, una evidente traslación de los «lugentes campi» virgilianos. En ese círculo, Dante, siempre en la compañía de Virgilio, contempla a su paisana y contemporánea Francesca de Rimini, en cuya boca pone unos versos sin duda inspirados por los que mucho antes había escrito su acompańante en la Eneida:

Amor, ch'a nullo amato amar perdona,

Mi prese del costui piacer sì forte,

Che, come vedi, ancor non mabbandona (V, 103-105) ${ }^{50}$.

Los comentaristas medievales de Dante no llegaron a advertir la adaptación bastante literal que el poeta italiano había llevado a cabo de uno de los versos de Virgilio que hemos citado antes. El primero que se dio cuenta de esa apropiación fue Bernardino Daniello, ya en la segunda mitad del siglo Xvi, hacia 1568:

Che, il quale piacer, ancor non m'abbandona, percioche ancora lo amava di là; onde è scritto da Virg. Nel sesto dell'Eneide: 'curae non ipsa in morte relinquunt ${ }^{\text {'51. }}$.

Dante menciona a Leandro cuando está a punto de cruzar, en el Purgatorio, el río Leteo, porque lo considera un obstáculo similar al que supuso para nuestro amante el Helesponto:

Tre passi ci facca il fiume lontani;

Ma Ellesponto [...],

Più odio da Leandro non sofferse

49. C. de Boer (1966: 89-90).

51. Bernardino Daniello da Lucca (1989:

50. Dante Alighieri (1989: 41).

302). 
Per mareggiare intra Sesto ed Abido.

Che quel da me perch'allor non s'aperse (XXVIII, 70-75) 52 .

El amante de Beatriz no ha compartido la interpretación que había propuesto porque, como acabamos de ver, conocía el sentido de la expresión «amor durus» al interpretarla literalmente cuando llama pensando en las sombras que recorren los «lugentes campi» al segundo círculo de su infierno el círculo de los lujuriosos. Entre las dos moralizaciones tan distintas que aporta el autor contemporáneo del Ovide moralisé, habría decidido no manifestarse claramente a favor de ninguna y optar por una intermedia que no lo comprometiera demasiado.

En su Ovidius moralizatus, el libro XV de su Reductiorum morale, del que hizo al menos dos redacciones (una de 1340 y otra de 1350), Pierre Bersuire expone las dos alegorías de nuestra fábula que había sugerido el autor del Ovide moralisé más una tercera cristológica que podría ser original.

Per Leandrum intelligitur luxuriosus; per Hero lujuriosa, que mediante facula carnis amoris ardentis facit fatuum ad se venire et horrenda pericula non timere.

Vel dic allegorice in bono significato quod Leander signat humanum genus, villa signat mundum, mare mortalem vitam, facula paradisum, Hero divinam sapientiam. Ista igitur veritas quod Hero i. divina sapientia valde a principio dilexit Leandrum i. genus Humanum, ita quod in ripa ubi erat s. ad celum summe atrahere cupiebat, et ideo ipsum a principio face i. lumine fidei et bonorum documentorum studuit illuminare et portum salutis viamque justicie demonstrare... Verum quia mare mortales vite et tempestas peccati Ade istum transitum impediebat, necesse fuit quo diste Leander s. genus Humanum mortem pene et culpe incurreret... quod s. videns Hero sapientia divina ad istum sic mortuum venit et a turre paradisi ad mare mortalitatis descendit.

Vel verte folium et dic quod Leander est Christus qui dum veniret ad amicam suam humanam s. animam visitandum... contigit quod in fluctibus tribulationum, flatibus invidie... fuit mortus et sepultus... ipse dilexit nos. Vel dic quod Hero est bonus prelatus... submergatur ${ }^{53}$.

['Por Leandro se ha de entender el lujurioso; por Hero, la lujuriosa, quien mediante una pequeña antorcha del amor ardiente de la carne hace al insensato venir hacia sí y no temer a los peligros horrendos. Este que desnudo y de noche nada hacia esta se dice que ha de denotar que los insensatos se desnudan de las riquezas y de los honores y hasta de la fama por las mujeres insensatas... Estos que acuden sucesivamente a través del mar denotan las muchas amarguras que tienen quienes aman carnalmente y por esto ambos acaban sumergidos en el mar... amarga como el ajenjo. $\mathrm{O}$ di alegóricamente en un buen sentido que Leandro indica el género humano, la villa el mundo, el mar la vida mortal, la pequeña antorcha el paraíso, Hero la sabiduría divina. La verdad es que Hero, a saber la sabiduría divina deseó mucho al principio a 
Leandro, a saber el género humano, así que a la ribera en la que está, a saber el cielo más alto, lo desea atraer, y por esto desde el principio con la pequeña antorcha, a saber con la luz de la fe y de los buenos ejemplos, intenta iluminar y mostrar el puerto de la salud y el camino de la justicia... Pero porque el mar de la vida mortal y la tempestad del pecado de Adán impide este tránsito fue necesario que este Leandro, a saber el género humano, se precipitó a la muerte por la culpa y la pena... que, viendo Hero, a saber la divina sabiduría, a este llegar muerto, descendió desde la torre del paraíso al mar de la mortalidad...

Y pasa el folio y di que Leandro es Cristo que mientras vino a visitar a su amiga humana, a saber el alma... ocurrió que en las ondas de la tribulación, en los vientos de la envidia..., fue muerto y sepultado... Él mismo nos amó. O di que Hero es el bien preferido... sumergido']

Francisco Petrarca, que había asesorado al autor del Ovidius moralizatus en su primera redacción, prefiere la interpretación más tradicional de la fábula al incluir a los dos amantes en el primero de sus Trionfi entre los seguidores del dios de Amor junto a otros muchos amantes que comparten con ellos su gran fidelidad y constancia (especialmente esposas fieles a sus maridos hasta la muerte):

[vedi] Leandro in mare ed Hero a la fenestra $(\mathrm{I}, 3,21)^{54}$.

Giovanni Boccaccio, en cambio, no dedica ni una sola línea a nuestros amantes (por no ser considerados dioses) en su conocida y difundidísima $G e-$ nealogia deorum gentilium, pero se refiere constantemente a ellos en casi todas sus obras escritas en italiano. En la Elegia di madonna Fiammetta, la protagonista homónima los menciona junto a Píramo y Tisbe y algunos otros amantes como ejemplos de quienes han sufrido mucho pero a quienes en la muerte supone felices por la posibilidad de seguir amándose en el otro mundo. Presenta a Hero bajando de su torre a la playa para recibir en su arena el cadáver de Leandro, cuyo rostro primero limpia con sus ropas y después lo baña con sus lágrimas ${ }^{55}$.

Otro poeta italiano, muy poco conocido, llamado Giovanni Girolamo Nadal, en el poema épico que hacia 1380 escribe sobre nuestra fábula, y que titula Leandreride, es el primero en incluir una serie de episodios que no aparecían en las fuentes que utiliza (fundamentalmente las heroidas de Ovidio). El primero y más importante es el inicial que narra el enamoramiento de los protagonistas durante la celebración de una fiesta en la ciudad en la que habitualmente reside la amada. Nadal dedica muchos versos al episodio en sí pero no parece usar para su elaboración un texto cercano al epilio de Museo porque no respeta esa peculiaridad del amor recíproco que lo hace distinto a otros. Si el poeta griego deja claro al principio de su poema que una misma flecha de Cupido hirió a los dos amantes, Nadal, en cambio, hace intervenir al mismo dios en la escena del enamoramiento pero

54. Petrarca (1996: 138).

prosa mitológica de Corella, como ha demos-

55. Ese pasaje constituye la fuente directa de la trado Josep Lluís Martos (2005: 257-275). 
para que arroje una flecha de oro a Leandro y una de plomo a Hero. El poeta italiano alarga desmesuradamente el episodio al obligar al amante a la mediación de la nodriza de la amada para lograr su seducción y la noche tan deseada.

Nadal también es el primero en situar claramente a los dos amantes, después de su muerte, en los «lugentes campi» o «mirthae... silva». Aprovecha el episodio en que imita claramente otro idéntico de la fábula de Céix y Alcíone para introducir la referencia a los campos en cuestión. Es el episodio en que saca a escena la sombra de Leandro, ya difunto, para anunciar a Hero no sólo su muerte sino también la espera en un lugar que llama de las «ombri grandi» (en posible alusión a lo que después Tasso identifica como el «bosco degli ombrosi mirti») y en el que poder seguir mostrando el amor que le había mostrado en vida:

Ché, come l'averai posto nel letto

De la sua sepultura, vaccio a le ombre

Grandi anderomi sponte, non constretto;

Ove uopo è ch'io te aspetti e poi mi isgombre,

Insieme, sempre unanimi, là giuso

Mostrando quanto amor qua su ne ingombre (XIII, 44-51) ${ }^{56}$.

Al final del poema, cuando ya ha narrado el suicidio de Hero, Nadal parece ubicar a los dos amantes en el infierno, a donde baja la diosa Venus para rescatarlos y asignarles un lugar en el cielo como estrellas. En ese punto de su relato, Nadal, siguiendo una tradición que remonta al poema alejandrino, como lo demuestra el epigrama de Antípatro de Sidonia, aclara que los dos amantes comparten una misma sepultura, porque en la muerte iban a estar tan juntos como lo habían estado en la vida:

Da cui il processo del so amor saputo,

Ordinaro che in una sola pira

L'un corpo e l'altro fosse riponuto... ... e doppo longo pianto

Fur sepiliti in una sepultura,

A la qual soprascrisser da l'un canto:

«Amor, che aveva fatto una alma pura

Di Leandro e de Hero, che son propinqui ivi,

Conduce insieme loro a morte dura

E morti atano insieme cum' fer vivi» (XVII, 58-70) ${ }^{57}$.

El poeta italiano reproduce a continuación el extenso parlamento que Venus dirige a Júpiter para pedirle en su nombre y en el de su hijo la transformación de sus dos fieles y seguidores en estrellas que han de adornar el cielo ${ }^{58}$. Júpiter se la concede y Venus, muy alegre, se encamina «a la contrada negra/ di Plutone» (IV, 10, 4-5) pa- 
ra entrar en el Tártaro porque en el lugar al que ha llegado ve primero a las Euménides y después a los gigantes castigados por los dioses. No muy lejos de allí reconoce a nuestros amantes junto a otras sombras con las que comparten idénticas penas:

Vide l'altre ombre che a pena eternale

Damnate sono; e vide insieme andarse

Leandro et Hero van gli amicis quale (IV, XIX, 22-24) ${ }^{59}$.

Para la transformación de los dos amantes en estrellas rutilantes del firmamento (lo que en mitología se conoce con el nombre de catasterismo), Nadal ha podido inspirarse en versos similares a los iniciales del epilio griego en los que su autor expone el deseo de que Zeus hubiera convertido en astro la lámpara que había usado Hero para guiar cada noche a su amante.

Los autores del siglo Xv aducen solo para la práctica pero nunca para la teoría a nuestros dos amantes. No los menciona Enrique de Villena en sus Doce trabajos de Hércules, ni Alonso Fernández de Madrigal en su libro de las Diez cuestiones vulgares, ni Juan de Mena en sus comentarios en prosa a La coronación del marqués de Santillana (esas glosas son un auténtico tratado de mitología que de manera literal utilizará Juan Pérez de Moya). Los poetas peninsulares sí que por lo general tendieron a citarlos en sus obras o compusieron en algún caso toda una recreación al completo de su historia.

A finales del siglo xIv, concretamente hacia 1390, Guillem Nicolau, sacerdote de la corte de Pedro el Ceremonioso y de Juan I el cazador, parece haber acabado la traducción de las Heroidas de Ovidio porque en 1389 se la reclama el rey y un año después la reina doña Violante de Bar, pero el sacerdote tarda en enviarles una copia con el texto porque aún no ha acabado las glosas que habrán de facilitar su comprensión. Antes de cada epístola incluye un prólogo (el conocido accessus medieval) en el que resume el contenido y aclara uno de los puntos básicos del género, la «intentio auctoris». De los dos accessus que presentan las epístolas correspondientes a nuestra fábula, solo en la segunda el rector de Maella trata ese punto pero en relación a su personaje no a los estudiantes (o también a los reyes) a los que parece dirigirse:

Entençió della és amonestar a Leànder que persever en la amor e que no am altra més que a ella ${ }^{60}$.

Esta versión catalana sirvió a su vez de modelo para una traducción castellana realizada por un autor anónimo en el primer tercio del siglo xv, y que no debe con-

58. Francisco de Quevedo (2004: 184), en uno de sus romances sobre la fábula, se hace eco de esa tradición al convertir a Leandro en estrella por mandato de Júpiter: «Pasó el mar en un gemido/ aquel espíritu noble;/ ofensa le hizo Neptuno,/ estrella le hizo Iove».
59. Nadal (1996: 157).

60. Los accessus de esta traducción ha sido editados en el apéndice de su trabajo por Josep-David Garrido y Valls (2002: 52); para el autor y el tipo de glosas, véase Josep Pujol (en prensa). 
fundirse con otra hecha en la misma lengua y también época por Juan Rodríguez del Padrón, el primer autor de la mal llamada novela sentimental. El poeta y prosista gallego, como el traductor anónimo, también puso al frente de cada epístola los famosos accessus en los que termina abordando el punto de la «intentio auctoris» (algo que no hace siempre Guillem Nicolau en su versión catalana). Juan Rodríguez del Padrón parece haberse inspirado en los accessus que había compuesto hacia 1200 el maestro Guillermo en Orléans en la obra De Bursarii super Ovidios, con quien coincide incluso en el título que le da a su traducción («este tratado es llamado por su semejante propiedad Bursarion) ${ }^{61}$. En los accessus a las heroidas XVIII y XIX, aparte de proporcionar la información necesaria sobre el contenido de la fábula, Juan Rodríguez desarrolla también, como Guillem Nicolau, pero en las dos ocasiones el punto de la «intentio auctoris», para orientarlo hacia una lectura moral de la epístola. A propósito de la primera de las heroidas, la de Leandro a Hero, identifica, siguiendo toda la tradición medieval, el amor del amante con el carnal:

La intención del actor es de reprehenderlo de loco amor, porque ponía su vida a peligro de muerte cada vez que iba a ver su amada ${ }^{62}$.

En la segunda de las cartas, en cambio, interpreta el amor de la amada como «lícito» porque la muchacha no deja de sentirlo en ningún momento y anima a su amante a hacer lo mismo:

La siguiente carta rescribe Hero a Leandro, en la cual su intención es la de amonestar a Leandro que sea constante, perseverando en su amor, en manera que no prefiera otra ninguna a ella. La intención del actor es de loarla de fidelidad, la cual se contiene so lícito $\mathrm{amor}^{63}$.

Inmediatamente a continuación de la heroida XIX reproduce una copla que atribuye a Pero Guillén de Segovia en que el autor menciona en los primeros versos a Leandro y a las sombras que le impiden cruzar el mar. Después aporta una interpretación alegórica de las distintas fábulas que ha recordado en esos versos. En el caso de Leandro sigue bastante de cerca las alegorías propuestas por el autor anónimo del Ovide moralisé y Pierre de Bersuire:

Por este Leandro podemos entender cualquier pecador que está navegando en las ondas marinas, que entendemos por este mundo en él mientra vive, al cual las sombras, que son los pecados, impiden o embargan que sea visto y visitado de la gracia de Dios, para que por ella venga en verdadera penitencia. Dice más la historia: que cada vez que Leandro había de pasar por aquel río Helos se ponía en peligro de muerte ¡0h, en cuánto peligro se pone homne cada vez que peca, que por cada pecado mortal es obligado ayunar vii años en este mundo, o estallos en el purgatorio! ${ }^{14}$

61. Véase William Engelbrach (2003: 50-59).

62. Juan Rodrigo del Padrón (1984: 183).
63. Juan Rodríguez del Padrón (1984: 190).

64. Juan Rodríguez del Padrón (1984: 199). 
Juan Rodríguez supone muy indirectamente a Leandro, al identificarlo con el pecador que muere sin la posibilidad de haber hecho penitencia, siete años en el purgatorio para alcanzar el paraíso una vez transcurrido ese tiempo.

No mucho después de Juan Rodríguez, en la década de 1460, el poeta valenciano Joan Roís de Corella compuso, con el título Història de Leandre i d'Hero, la prosa mitológica que dedicó a nuestra fábula. La contaminó aún mucho más que Nadal con la de Céix y Alcíone, como veremos en seguida, y también con la Píramo y Tisbe al hacer que Hero se suicidara con un cuchillo que llevaba Leandro.

Corella introdujo en su prosa una serie de episodios y detalles que en principio (y mientras no se demuestre lo contrario) sólo pudo conocer a través del epilio de Museo. Al adoptar el ordo naturalis para su relato tuvo que incluir el episodio del enamoramiento de los personajes. Es un episodio que, como hemos visto ya, sólo ofreció Museo, y después del gramático griego Giovanni Girolamo Nadal, que lo reconstruye a partir de otra fuente, seguramente medieval. El episodio, como hemos visto, presenta la peculiaridad que ya hemos destacado y que Nadal no respeta tal vez por no conocer el epilio griego. Corella también sitúa el encuentro de los protagonistas en una fiesta celebrada en la isla de Sestos pero no brinda ningún dato que permita identificarla como de Venus. Si no lo hace puede ser porque no lo considere relevante o porque piense que la diosa (al ignorar que hubiera una 'virgen') nada tiene que ver con la castidad en la que vive la protagonista. Pero es muy evidente que el poeta valenciano, a diferencia de Nadal, a quien para ese punto del episodio no sigue, presenta el enamoramiento de nuestros personajes como mutuo y recíproco desde el mismísimo instante en que los dos intercambian sus miradas. Es posible que haya reconstruido el episodio a partir de otro casi idéntico protagonizado por París y Helena, quienes en el templo de la diosa Venus, durante la celebración de una fiesta dedicada a la diosa, se ven por primera vez y se enamoran mutuamente. El episodio, seguramente inspirado por las heroidas dobles de esos dos personajes, lo narra de esa manera Guido della Colonne en su Historia destructionis Troiae, que la había acabado de componer en 1287. De no haber otros detalles que lo vincularan al poeta griego podría pensarse que el valenciano había usado la obra del juez de Mesina para reconstruir el episodio inicial de su prosa.

En ese episodio inicial precisamente Corella introduce en la fábula (por primera vez en la Edad Media) el tema del amor conyugal al hacer que Leandro piense en el matrimonio cuando negocia con la nodriza de Hero una cita con su señora. Para ese tratamiento del amor de los protagonistas podía haberse inspirado en la fábula de Céix y Alcíone porque sus personajes son esposo y esposa desde el inicio de la acción. Pero tampoco cabe descartar que hubiera conocido (aunque sea parcialmente) el epilio griego por ser Museo el único autor antiguo en plantear abiertamente el amor conyugal entre nuestros amantes.

A pesar de ese tratamiento del amor, Corella no reproduce ningún himeneo entre los amantes ni tampoco dedica ninguna línea a la narración de su en- 
cuentro en la playa ni por supuesto en el aposento de la amada. Para esa parte de la fábula, tal vez no disponía de esa versión del poema griego, y de haberla dispuesto o conocido, igual prefirió no utilizarla, como tampoco utiliza las dos heroidas de Ovidio al no aludir para nada a las llegadas de Leandro a la playa de Sestos ni a su recibimiento en su arena por parte de Hero. Es posible que no tuviera interés (por razones de distinta índole, también de tipo moral) en ofrecer algún detalle sobre la intimidad de los dos amantes. De hecho traslada la escena del recibimiento en el mar en vida a la escena final del recibimiento también en el mar pero ya en muerte.

Pero al narrar la agonía de Leandro entre las olas del Helesponto el poeta valenciano parece seguir otra vez (y también ocasionalmente) la versión de Museo. Cuando describe el proceso de ahogamiento de nuestro amante se refiere al agua que el nadador ha podido tragar y no traga por impedírselo el nombre y el amor de Hero que pugna por salir de su boca. Cuando llega al momento de certificar la muerte de nuestro protagonista Corella aporta una serie de detalles que toma de la de Céix producida en idénticas circunstancias ${ }^{65}$. Leandro, ya a punto de ser engullido por las olas, dirige la mirada a la torre en la que lo espera Hero y pronuncia un breve monólogo que termina al mismo tiempo que su vida con la última sílaba de la amada:

E, si un poc espai lo cap de les ones alçava, reclamant lo nom d'Hero escopia l'aigua salada, la qual, ab terrible perfidia, volia entrar en lo cos de Leànder; però l'amor d'Hero així tot l'ocupava, que a les amargues aigües l'entrada defenia $[\ldots]$ i ab l'agonia de la mort que ja l'assaltava, dreçà los ulls a la torre d'Hero, per qui moria, i, abandonat a la fúria de la mar tempestuosa, ensems ab l'ànima tals paraules se partiren:

Cuita, cos mort, que l'amor que et fa perdre

Te guiarà fins al peu de la torre ${ }^{66}$ :

Seguint del foc la miserable ensenya,

Fes-te present a la plorosa Hero.

65. En un trabajo fundamental para nuestra fábula, Josep Pujol (en prensa) ya había advertido la contaminación de la prosa de Corella con la fábula dee Céix y Alcione. Agradezco a su autor el haberme dejado de leer su original. 66. Es sorprendente que el "pie de la torre», que sólo la menciona Museo (no lo hace Servio ni tampoco Ovidio), aparezca también en una obra muy anterior a la primera edición del poema griego. La obra a la que me estoy refiriendo es el Libro de las veinte cartas e quistiones (seguramente anterior a 1446) de Francisco de la Torre: «Ha de ser la figura de la sota de la historia de Vinus como venía por la mar a nado de ver a su amiga Merus, que está en una torre de una isla, e como lo mata la tormenta e así muerto lo lieva al pie de la dicha torre, e como ella lo ve se mata por una espada». Francisco de la Torre latiniza el nombre de los personajes y llama a Leandro por el nombre de la ciudad de donde era natural (Abidus). Está claro que "Vinus» es un mala lectura de "Abidus» (escrito posiblemente sin la «a» inicial) y «Merus» de «Herus». Para explicar esta referencia al pie de la torre José María Cossío (1929: 174-175) postulaba la existencia en Francia, que es donde estuvo Francisco de la Torre hasta 1457 , de una traducción latina de Museo anterior a esa fecha. 
La darrera síllla ba del nom d'Hero en aquest món fón terme del seu parlar, amar e viure... ${ }^{67}$

Para esa forma de morir sin duda ha tenido en cuenta la de Céix, quien también al lidiar contra las olas del mar antes de sucumbir definitivamente a ellas endereza el rostro hacia el hogar conyugal y tiene las fuerzas suficientes para en esa lucha agónica por la supervivencia pronunciar el nombre de su esposa Alcíone:

Patriae quoque uellet ad oras

Respicere inque domum supremos uertere uultus, verum ubi sit, nescit....

nam plurima nantis in ore est

Alcyone coniunx: illam meminitque refertque,

Illius ante oculos ut agant sua corpora fluctus,

Opta, et examinis manibus tumuletur amicis;

Dum natat, absentem, quotiens sinit hiscere fluctus,

Nominat Alcyonem ipsisque inmurmurat undis.

Ecce super medios fluctus niger arcus aquarum

Frangitur et rupta mersum caput obruit unda ${ }^{68}$.

['También quiere volver la mirada a las orillas de la patria y dirigir por última vez el rostro al hogar.... porque mientras nada es a su esposa Alcíone a la que tiene en la boca siempre; y a ella recuerda y nombra, y desea que las olas lleven su cuerpo ante ella, y sin vida sea enterrado por las manos amadas; mientras nada, pronuncia el nombre de la ausente Alcíone cuantas veces se lo permiten las olas, y lo murmura en las propias aguas. He aquí que sobre las olas que lo arrastran se rompe un oscuro arco de aguas y la cabeza sumergida se hunde por las olas deshechas'].

En Le Roman de Tristan, fechado hacia 1173, Thomas de Ingalterra hace que el protagonista muera también diciendo el nombre de la amada el número concreto de cuatro veces (Ovidio no contabiliza las de Céix, pero da a entender que son bastantes):

-Amie Ysolt' - treis feiz dit,

A la quarte rent l'espirit ${ }^{69}$

Pero el poeta valenciano para este episodio, como ya anunciábamos antes, ha podido conocer una versión si no idéntica al menos cercana a la de Museo: afirma que al pronunciar la última sílaba del nombre de la amada el amante puso fin al mismo tiempo a su habla, a su vida y también a su amor. Esta frase con los tres miembros Corella podría haberla directamente de un texto prácticamente igual al de Museo: 


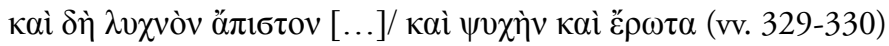

Iamque facem infidam $[\ldots]$ /Atque animam $[\ldots]$ que $[\ldots]$ amorem parlar viure amar

El verso de Museo y la frase de Corella son casi idénticos pero entre el uno y la otra hay una diferencia: el valenciano sustituye $\lambda v \chi v o ́ v$ (el «facem» de Guillermo de Mara) por "parlar», porque mantiene el «foch» encendido para que sirva de guía al cadáver de Leandro, cuya boca, al llegar en presencia de la amada, conserva el gesto articulatorio para poder pronunciar todavía su nombre (es en este momento cuando el «foch» debe apagarse y con él también el amor, como en Museo, y no antes):

Hi en la boca morta aquell gest guardava, ab lo qual lo nom de Hero se pronuncia ${ }^{70}$.

Corella también había podido inspirarse en uno de los versos que Ovidio atribuye a Leandro cuando imagina su muerte engullido por el mar: "Aut mors solliciti finis amoris erit!» (v. 196). Si bien puede haber cierta coincidencia con el poeta latino, especialmente en el léxico ("fón terme del seu... amar», 'finis amoris erit»), tampoco se puede negar que también la hay con el gramático griego (en la elección de tres términos que llegan a su fin al mismo tiempo y la relacción directa que establece entre vida y amor).

El poeta valenciano no ha sabido o no ha querido eliminar una de las tres palabras que contenía los dos versos de Museo (y también el de Ovidio) aun a costa de contradecirse al desarrollar después, como veremos más adelante, el tema del amor que sobrevive a la muerte de los amantes. Antes que Corella, el florentino Filippo Ceffi, hacia 1325, en el prólogo que escribe resumiendo la fábula, antes de empezar la traducción de la heroida de Leandro a Hero, también parece recordar, si no todo, parte del verso de Museo al narrar la muerte de nuestro amante:

Al quale ella per sua letrera rispose, sollicitandole con dolei e amorose parole per del todo venire. Onde egli sfrenatamente si mise a passare e non potendo fendere la tempestose onde, affogando perderte la vita e l'amore e per uno delfino fu gittato alla proda della sua amante tutto ignudo ${ }^{71}$.

Ceffi sólo ha reproducido dos elementos porque no busca ningún equivalente para la antorcha o lámpara que en el poeta griego se apaga junto a la vida y el amor de Leandro. Es posible, en cualquier caso, que el teólogo valenciano haya usado una tradición (posiblemente italiana) sobre la muerte de su protagonista en que recogiera ese verso de Museo. 
Pero Corella sigue claramente la tradición inaugurada por Baldric de Bourgueil y Nadal cuando acaba proponiendo también el tema del amor ultraterrenal. Describe los cuerpos de los amantes abrazados en una misma sepultura y sus almas también enlazadas para siempre en un lugar no especificado de los reinos de la muerte. En ese punto parece demostrar un conocimiento directo del poeta italiano al poner en boca de Hero cuando se le aparece la sombra de Leandro la ubicación de su alma en los «lugentes campi» (en Nadal era el propio amante difunto el que hacía saber esa ubicación):

Comporta que al teu cos meu yo donc sepultura hi, aprés, ensemps ab la mia, devallaràs als regnes de Plutó, perque un carçre, una pena, unes cadenes, aprés la mort liguen aquelles dues ànimes les quals una amor havia liguat en vida... Hi en un sepulcre tan estret nos tanque, que.ls postres ossos mesclats a la fi en una pols se converteixquen. $\mathrm{Hi}$, en lletres gregues, sobre la nostra tomba, senblant epitafio escolpit escriva:

"Amor cruel, qui.ls ha units en vida,

Y ab gran dolor lo viure.ls ha fet perdre,

Aprés la mort los tanqua.n lo sepulcre» ${ }^{72}$.

Corella tampoco necesitaba dar demasiados detalles sobre la identificación de ese lugar en que las almas de Leandro y Hero seguirán unidas y entrelazadas como cuando vivían en sus respectivos cuerpos. En otra de sus prosas mitológicas, conocida con el título de Lamentacions, ofrece más datos y más precisos sobre el lugar que ocupan las almas que conservan el amor que han tenido en vida al narrar su descenso al Hades para oír sus quejas:

Ab desig de trobar a ma dolor semblant companyia, he desemparat aquest món, devallant en los trists e tenebrosos palaus de Plutó, per aquell camí que al desterrat de Troya mostrà la ínclita sibilla. E, així, só arribat en aquell adolorit verger, en lo qual los devots de Venus, en continu plor, lurs penes reconten... ${ }^{73}$

Corella se muestra muy cabal al llamar a ese lugar con el adjetivo "adolorit» y el sustantivo «verger» porque de manera bastante evidente une el adjetivo de «lugentes campi» con el sustantivo en plural de «myrtae... silva»: «lugentes... silva[e]», «adolorit verger». Igual de preciso se muestra al denominar a sus habitantes «devots de Venus» pensando precisamente en las «myrtae», árboles de esa diosa, bajo los que se ocultan las sombras que siguen amando ${ }^{74}$.

Los poetas castellanos del siglo XV no recrearon la fábula en ninguna de sus partes pero sí adujeron a sus protagonistas en las listas de amantes famosos que incluyeron en las obras en las que alternaron la imitación del infierno de Dante con

72. Corella (2001: 172-173).

73. Corella (2001: 175).

74. Para la alusión de Corella a estos versos de Virgilio, véanse Stefano M. Cingolani (1998: 184); y Josep Lluís Martos (2001: 72-73). 
el triunfo de amor de Petrarca. El marqués de Santillana, antes que Corella, los cita al final del soneto XX y los incluye en el infierno de los enamorados en un lugar habitado por amantes en el que los puso «su deseo ferviente» (v. 367). Aunque para llegar al lugar en cuestión ha debido cruzar la puerta de un alcázar está claro que el marqués lo identifica con los «lugentes campi» (o el círculo de los lujuriosos de Dante) porque sus ocupantes han padecido en vida ese «deseo ferviente» (más o menos equivalente al «amor durus» virgiliano») y porque todos llevaban el pecho «foradado» por «el siniestro lado», en una clara alusión a la Dido que precisamente vagaba por esos campos con la herida abierta a la altura del corazón.

Juan del Encina, siguiendo la tradición inaugurada por Nadal, también sitúa a Leandro y Hero en los «lugentes campi», en el primero de sus triunfos de amor (el narrativo y no pastoril) que ya publica en su primer Cancionero (Salamanca, 1496). Encina los llama «bosque de arrayanes» (o también «triste boscaje»), al traducir bastante literalmente los «mirthae... silva» de Virgilio, cuyo libro VI de la Eneida cita explícitamente con esos datos del autor y del libro de la obra. En ese bosque contempla a muchos hombres y mujeres, «todos [...] ya muertos», «en amores desdichados», entre los que también reconoce a nuestros amantes:

Y también Leandro y Hero,

Según que me pareció,

Con amor muy verdadero

$\mathrm{Vi}$ que en un estrecho fiero

Uno por otro murión ${ }^{75}$.

Como Corella, el salmantino llama "muy verdadero» al amor de nuestros personajes no porque lo considere puro y espiritual sino porque entiende que no se extingue ni con la llegada de la muerte. Es un adjetivo que reserva al amor duradero y constante de quienes pueblan los «lugentes campi» o «mírate... silva».

\section{La fábula en el Renacimiento}

En el Renacimiento nuestra fábula no aparece mencionada ni comentada en las grandes obras de mitología. Nada dicen de sus personajes ni Natal Conti ni Gregorio Lilio Giraldo ni Vincenzo Cartari. Sólo se refiere a ellos Juan Pérez de Moya en su Filosofía secreta (Madrid, 1585) para centrarse exclusivamente en la aplicación moral o alegórica de su historia, que no resume por considerarla ya muy conocida y divulgada. Para la explicación alegórica se ha limitado a traducir casi palabra por palabra la que había propuesto Fulgencio:

Por ser a todos notorio la historia o ficción de Leandro y Hero, diré solamente que el amor las más veces se acompańa y concuerda con peligros. Eros en griego

75. Juan del Encina (1978: 101). 
quiere decir amor, y Leandro, soltura de varones, porque la soltura y la libertad del hombre cría amor. Nada de noche, esto es que en tiempo oscuro tienta los peligros. Ero, también en semejanza del amor, se finge traer la luz, porque el amor no trae otra cosa sino llama y muestra el peligroso camino al deseoso, mas presto se mata, porque el amor del mancebo no dura mucho. Nada desnudo, porque el amor sabe desnudar a los que le siguen y arrojarlos en los peligros y amarguras, como en la mar, porque muerta la candela, se procuró la muerte marítima de ambos, esto es que, apagado el vapor de la edad en el hombre y en la mujer, se muere juntamente la lujuria, y son echados muertos en la mar, como en humor de la fría vejez, porque todo fuego de la encendida mocedad se resfría en esta edad ${ }^{76}$.

El primer autor del Renacimiento que decide ofrecer -después del soneto que Garcilaso compuso en los años finales de su vida - una nueva versión de la fábula es Bernardo Tasso, quien la incluyó como último poema del libro III de los Amori (Venecia, 1537). Tasso adopta como modelo el epilio de Museo pero también emplea para aspectos muy concretos las dos heroidas de Ovidio. Para la escena del recibimiento de Hero a Leandro, por ejemplo, se ha decidido por las segundas al elegir los cabellos como la parte del cuerpo que la amada seca al amante. Pero en esa elección ha dado un paso más y ha aportado un detalle que, en la línea del que ya había sugerido Baldric de Bourgueil, contribuye a cristianizar aún más la fábula. En la escena en cuestión, Hero no se limita a secar los cabellos de Leandro sino que también los perfuma (los unge con ungüentos muy cosotosos):

E ne la stanza, secretaria fida

Degli amorosi suoi novi desiri,

Pien di gioia infinita lo conduce,

Ove i biondi capelli, ancor stillanti

Il salso umor de la marine schiume,

Asciutti con licor pregiato e caro,

Fece l'odor de l'alghe andar lontano... ${ }^{77}$

Tasso parece recordar una de las dos versiones de la unción de Jesús por una mujer que narran los evangelistas canónicos. La versión que el poeta italiano ha tenido en cuenta es la recogida por tres de los cuatro evangelios: Mateo (25, 6-13), Marcos (14, 3-9) y Juan (12, 1-8). En esa versión la mujer (una vez se la llama María y se la suele identificar con la Magdalena) aparece en la ciudad de Betania (dos en casa de Simón y una en la de Lázaro) y se califica el ungüento con el adjetivo "pretiosi» 'de precio elevado', 'costoso' (es el «licor pregiato e caro» de Tasso); pero sólo en dos evangelios (Mateo y Marcos) el ungüento la mujer lo derrama sobre la cabeza (y no los pies) de Jesús:

Et cum esset (Iesus) Bethaniae in domo Simonis leprosi, et recumberet, venit mu- 
lier habens alabastrum unguenti nardi spicati pretiosi, et fracto alabastro, effudit super caput eius (Marcos, 14, 3-5).

['Y cuando Jesús estuvo en Betania, en casa de Simón el leproso, y se sentó a la mesa, llegó una mujer que traía en un vaso de alabastro ungüento de nardo de precio elevado, y, rompiendo el vaso, lo derramó sobre su cabeza']

Cum autem Iesus esset in Bethania in domo Simonis leprosi, accessit ad eum mulier habens alabastrum unguenti pretiosi, et effudit super caput ipsius recumbentis $(\text { Mateo, 26, 6-7 })^{78}$.

['Pero cuando Jesús estuvo en Betania, en casa de Simón el leproso, y se acercó a él una mujer que traía en un vaso de alabastro ungüento de precio elevado, y lo derramó sobre su cabeza cuando él estaba sentado a la mesa']

Un autor medieval anónimo (de hacia 1260) traduce al castellano el evangelio de san Mateo interpretando "pretiosi» exactamente con la misma palabra que utiliza Tasso en italiano:

Estando Ihesu Christo en Bethania, en casa de Symón el malato, acostos' a una muger que traye ungüento preciado e puso dello en la cabeza de Ihesu Cristo ${ }^{79}$.

En los tres evangelios es el propio Jesús el que interpreta el gesto de hospitalidad de que ha sido objeto en Betania haciendo saber a sus discípulos (y especialmente a Judas) que la mujer al ungir parte de su cuerpo no ha hecho más que anticipar la que María Magdalena y otras dos mujeres practicarán en su cadáver siete días después antes de introducirlo en su sepultura (Marcos, 16, 1; Lucas, 23, 56; y Juan, 19, 40). Con esa alusión bíblica Tasso también habría querido de alguna manera anunciar la muerte de su protagonista (Hero lo unge como si fuera ya un cadáver), pero no queda claro si pretendía además transmitir el mismo mensaje de redención y salvación que los evangelistas. En el siglo XVII, por ejemplo, pensando precisamente en esa función redentora de la unción, Andrés Rey de Artieda identifica el ungüento con la cruz en la que murió Jesucristo:

Que, informadas las señoras

De tu estado peligroso,

Con el ungüento precioso

Del crucifixo que adoras

Vienes a darte reposo ${ }^{80}$.

En una también evidente moralización de la fábula, Tasso describe el himeneo secreto de Leandro y Hero sin uno de sus elementos más característicos, que

78. Alberto Colenga y Laurentio Turrado (1982: 1006 y 927-928).

gomery y Spurgeon W. Balwin (1962: 66).

79. El texto está publicado por Thomas Mont-

80. Antonio rey de Artieda (1955: 235). 
es el momento en que el esposo desciñe la cinta o cinturón (la "zona» en latín) del vestido de la novia como paso previo pero inevitable a la rendición de su virginidad. Ha preferido narrar ese momento de la consumación del himeneo con referencias menos comprometedoras y más vagas (y también eufemísticas):

Così diss'ella, et ei pien di desio

Ne la fonte d'Amor, sin a quel tempo

Da la santa honesta guardata e chiusa,

Le labbra immerse, né la sete spense,

Anzi del dolce umor la voglia accrebbe ${ }^{81}$.

$\mathrm{Al}$ igual que Corella, el poeta italiano contamina muy claramente con la fábula de Céix y Alcíone, al poner en boca del uno el nombre del otro en el instante en que pierde la vida y al suponer también que el amor de los dos sobrevive a su propia muerte. Ha sido más original que el valenciano al elegir a Hero (y no a Leandro) como el personaje al que hace pronunciar el nombre del amado al exhalar el último aliento de vida. Para la narración de esa bella forma de morir no ha adoptado la de Céix en las Metamorfosis de Ovidio sino la de Orfeo en las Geórgicas de Virgilio:

Finita fu, la disparata moglie

Col marito abbracciata si sommerse,

Dicendo ancor con la gelata lengua:

«Ah, misero Leandro!' A la cui voce

Risuonò l'onda: «Ah, misero Leandro!! ${ }^{82}$

Si la cabeza de Orfeo rueda por el río Hebro pronunciando, a pesar de tener ya la lengua fría, el nombre de Eurídice y provocando de ese modo el eco a través de sus aguas, la cabeza de Hero, sin haber sido decapitada pero con la lengua igualmente helada, antes de hundirse en el mar, logra articular el nombre de Leandro, cuyas ondas lo repiten también con el mismo efecto de eco.

El poeta inglés George Chapman, que acabó el poema que Chistopher Marlowe había dejado incompleto, publicó su parte junto a la de su amigo en 1598 con el título Hero and Leander. La versión de Champan contrasta con la de Marlowe porque el primero fue el más moralista de los poetas de la época mientras el segundo, como lo demuestra en su parte, había escandalizado la sociedad inglesa por su ateísmo y sobre todo por sus blasfemias (además también por su conducta inmoral). Para su parte Chapman ha utilizado el poema de Tasso porque narra la muerte de Hero de la misma manera que el italiano. La protagonista descubre al amanecer el cadáver de su amante en la playa (no intenta divisarlo desde su torre) y se abalanza sobre él para morir de dolor pegada como una lapa a su 
cuerpo. Neptuno, el mar, los acoge por piedad en su seno para arrojarlos al aire y convertirlos en jilgueros.

He saw him, and the sight was much much more

Than might have served to kill her: should her store

Of giant sorrows speak? Burst, die, bleed,

And leave poor plaints to us that shall succeed.

She fell on her love's bosom, hugged it fast,

And with Leander's name she breathed her last.

Neptune for pity in his arms did take them,

Flung them into the air, and did awake them

Like two sweet birds, surnamed th'Acanthides,

Which we call thistle-warps, that near no seas... ${ }^{83}$

En Chapman Hero también en el momento de su muerte pronuncia el nombre de Leandro: 'y con el nombre de Leandro ella exhaló su último suspiro' ("And with Leander's name she breathed her last»). Pero es que además Chapman ha empleado directamente la fábula de Céix y Alcione al presentar a Leandro y Hero transformados en jilgueros (Ovidio había transformado su pareja de amantes en alciones).

El italiano prevé para los dos amantes el mismo lugar en el más allá que los autores medievales (al menos desde Nadal) cuando lo identifica de manera tan clara con el «bosco degli ombrosi mirti» (la «myrtae... silva» de Virgilio), pero a ese lugar añade otro, el de los Campos Elíseos, probablemente pensando en su salvación:

Donate i corpi morti a sepultura,

Acciò possin varcar insieme aggiunti

Le nere e torbid'acque di Cocito,

E gira ai lieti e fortunati campi,

O pur nel bosco degli ombrosi mirti (vv. 671-67) $)^{84}$.

Si Tasso parece dudar entre los dos lugares es porque por un lado habrá querido imaginar a sus personajes en una especie de paraíso pagano al querer salvarlos de todos sus infortunios pero por otro no habrá podido sustraerse a la tradición que los presentaba como ya habituales pobladores de unos campos con su bosque de mirtos exclusivos de los que habían amado en exceso en vida.

\section{La moralización de Boscán: la defensa del amor conyugal}

El poeta Juan Boscán ha insistido tanto o más que Museo en disfrazar o revestir el amor de los dos personajes de amor conyugal porque, como señalábamos al principio de este trabajo, pretendía proyectar en él su propia experiencia de 
hombre que acababa de contraer matrimonio cuando inició la composición de su poema. Convierte la fábula entera en una exaltación del amor conyugal, al igual que había hecho en el libro II de sus obras poéticas (y en parte también en el I).

Boscán presenta a Hero engañada cuando se enamora de Leandro por hacer que ella confunda el sentimiento que está experimentando con otro muy distinto al que en el fondo experimenta. La doncella piensa que el amor que le inspira su amante es casto y honesto cuando verdaderamente es lascivo y carnal. El poeta barcelonés para expresar semejante dicotomía recurre a un lenguaje médico: identifica el primer amor con uno de salud (usa dos veces el adverbio «sanamente») y el segundo con otro de enfermedad (emplea específicamente el sustantivo "pestilencia»). Para la dicotomía podía haber tenido como modelo a Garcilaso, quien en la égloga II atribuye a Albanio una prácticamente igual o muy similar, al llamar «sano» (v. 184) el amor «lleno de pureza» que siente el pastor por Camila cuando es un niño e «insano" (v. 1093) el otro que padece cuando ya adolescente la empieza a mirar "con terrible y fiero desear».

Boscán ya había introducido esa dicotomía entre los dos amores, con idénticos calificativos procedentes de la medicina, en el libro II al vincularlos con su situación personal de abandono en la corte de un tipo de vida para empezar otro en su Barcelona natal junto a la que años más tarde acabará convirtiéndose en su esposa. En ese libro II toma como modelo el Canzoniere de Petrarca al contar a través de sonetos y canciones la renuncia al un tipo de amor para adoptar otro mucho menos dañino y más casto. Si bien nunca bautiza ese segundo amor con el calificativo de conyugal (o con un término equivalente) en una ocasión lo define de la misma manera que León Hebreo en sus Dialoghi d'amore cuando el portugués se refiere explícitamente al amor dentro del matrimonio. El barcelonés es todavía más explícito cuando en la epístola dirigida a Diego Hurtado de Mendoza, incluida en el mismo libro que nuestra fábula, admite haberse casado «con una mujer» (v. 128) y presenta el amor que siente por ella como un amor distinto al que había sentido antes por otras mujeres (en clara alusión a la vida que llevaba en la corte en torno al tercer duque de Alba). En esa epístola, define una vez el nuevo amor como "casto" (v. 163), al igual que hace también en el libro II (CCXXVII, v. 6), y califica de «sanos» los pensamientos que le inspira su esposa (v. 174). Está claro que distingue entre un amor de enfermedad (prefiere la palabra "dolencia», como en los sonetos CXVIII, v. 13) y CXXVII, v. 10), y otro de salud, que además identifica con el conyugal. Pero, a pesar de considerarlo casto, como ya hemos visto, entiende que no lo es del todo porque en la epístola a Diego Hurtado de Mendoza alude a los placeres sexuales que comparte con su esposa por la noche y que decide dejar de contar pensando en el decoro de su pluma (vv. 340-342).

Cuando describe el enamoramiento de Leandro y Hero, como hemos visto ya, Boscán también se refiere a esos dos tipos de amor, pero no los presenta como el resultado de una evolución de uno hacia el otro (es la gran diferencia con respecto al libro II y la epístola a Mendoza) sino como experimentados los 
dos en el mismo instante por el personaje que se enamora al mirar por primera vez al otro. Si Hero los confunde es porque en el fondo no hace más que sentir los dos, pero de los dos la muchacha sólo sabe reconocer el honesto por la educación que ha recibido y la vida que ha llevado recluida en la torre en la que practicará los dos con su amante-esposo. En su primer diálogo en el templo, Leandro le propone a Hero explícitamente el matrimonio (vv. 649-650); y si no lo ejecutan públicamente, a diferencia de lo que ocurre en la novela bizantina en la que Museo se inspira para su epilio, es por la rivalidad entre sus dos familias. Ante esa situación, nuestros amantes no tienen más opción que una boda secreta, que de algún los exculpe o atenúe su pasión amorosa.

Para esa dicotomía que plantea entre dos tipos de amor desde un punto de vista médico, Boscán sigue sin duda una tradición que remonta directamente a Platón y a su Banquete (180 b-e). En ese diálogo, el filósofo griego hace intervenir al médico Erixímaco para distinguir en un discurso pseudo-científico entre dos tipos de amor, que vincula con los estados naturales del cuerpo, uno de salud y otro de enfermedad:

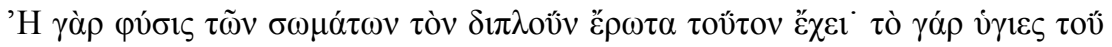

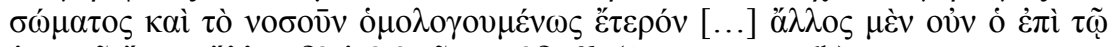

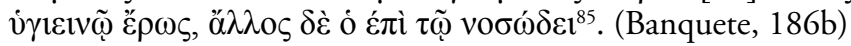

['La naturaleza del cuerpo sin duda conlleva este doble amor, porque para el cuerpo, según una idea unánime, el estado sano y el estado enfermo son diferentes [...] Uno es el amor de lo que está sano y otro es el amor de lo que está enfermo']

Erixímaco ha empezado relacionando claramente esos dos amores con las dos Afroditas, la Urania ('celeste, inmaterial') y la Pandemo ('vulgar, corriente'), que en su intervención anterior ha diferenciado Pausanias. Como resultado de esa asociación el médico considera el amor de salud como un amor en el que quienes lo practican tienen más en cuenta el alma que el cuerpo y el de enfermedad como otro en que precisamente sus defensores sólo aspiran a la posesión del cuerpo y a la relación sexual.

Boscán pudo haber leído ese pasaje del Banquete en la lengua original (no necesitaba saber mucho griego para hacerlo), pero también había podido utilizar la versión latina que Marsilio Ficino había dado a conocer a finales del siglo Xv y que seguiría publicándose en el siglo xvi:

Corporum sane natura amorem hunc geminum continet. Quod enim in corporibus nostris bene valet $\&$ quod male aliudque dissimile esse constat [...] Alius ergo qui in sano corpore amor, alius qui in aegroto ${ }^{86}$. 
['La naturaleza de los cuerpos sin duda contiene este doble amor. Porque en nuestros cuerpos es cosa sabida que lo que está bien y mal de salud es distinto y diferente [...] Una cosa es por tanto el amor en un cuerpo sano y otra el amor en un cuerpo enfermo'].

En su poema Museo, que había leído muy bien a Platón, se refiere a las dos

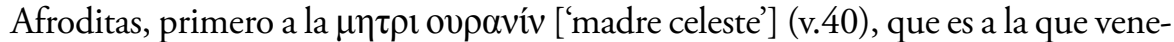

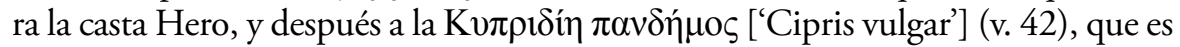
la Afrodita por la que en Sestos se celebra una fiesta dedicada a ella y a su amante Adonis $^{87}$. Da la impresión de que nuestro misterioso gramático asocia la primera Afrodita con la castidad de Hero y la segunda con el amor carnal de los dos amantes, pues hace que se conozcan y enamoren no demasiado castamente en una fiesta celebrada en su honor. Boscán sin duda debió reconocer en los versos de uno de sus incuestionables modelos esas dos Afroditas y el sentido que le atribuyó el autor que las adujo en lugar tan proeminente como es al inicio de su poema. Guillemo de Mara las denomina «Caelestem... matrem» y «Neptunia Cyprus» ['Cipris neptunia, hija del mar'], y el comentarista no atina a relacionarlas con las dos Afroditas de Platón cuando, a propósito de la primera, identifica a Venus con el planeta que determina el carácter lujurioso de quienes nacen bajo su ascendencia e influencia.

Para la distinción de esas dos Afroditas, Museo pudo haber tenido en cuenta la novela en que Caritón de Afrodisias parece también haberla introducido en circunstancias muy similares. Al describir la belleza divina de Calírroe, el novelista griego la compara con la misma 'A $\varphi \rho \circ \delta i َ \eta \varsigma ~ \Pi \alpha \rho 9 \varepsilon \dot{\varepsilon} v 0 v$ ['Afrodita Virgen'], en una posible referencia a la Afrodita Urania; y un poco después menciona la

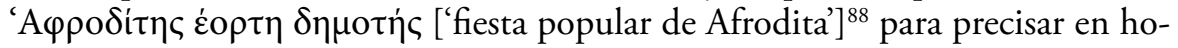
nor de qué diosa se celebra la fiesta que propicia el encuentro de la muchacha con Quéreas fuera del templo (si bien usa $\delta \eta \mu$ oń

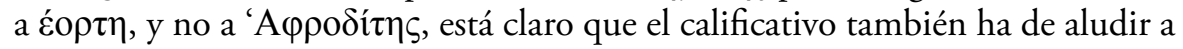
un tipo determinado de Afrodita).

El pasaje del Banquete de Platón sobre las dos Afroditas había sido objeto de una reinterpretación en clave conyugal por los autores de la época helenística, quienes relacionaron la Afrodita Urania o celeste con el matrimonio y la Pandémica o vulgar con el apetito sexual ${ }^{89}$. En su Descripción de Grecia (VI, 25) Pausanias sitúa en la zona de Élide un templo dedicado a Afrodita que conserva dos estatuas de la diosa, una de la Afrodita Urania y otra de la Afrodita Pandemo. La primera estatua, hecha de mármol y oro por Fidias, reproduce a la diosa de pie y con uno de los dos apoyado sobre una tortuga; la segunda, en cambio, esculpida con bron-

87. Antonio Villarrubia (2000: 378) es el que ya ha distinguido la referencia a esas dos Afroditas en el poema de Museo.

88. Chariton, (1979,: 50).

89. José Carlos Fernández Corte y Juan Anto- nio González Iglesias, en las notas a su edición de Catulo (2006: 608), recuerdan esta reinterpretación que se lleva a cabo en la época helenística pero no menciona ningún autor ni texto para documentarla 
ce por Escopas, la muestra sentada sobre un macho cabrío. Pausanias no cree necesario explicar los símbolos de esos dos animales, porque sabe que la tortuga lo es del amor conyugal y el macho cabrío del apetito sexual ${ }^{90}$. Es posible que se llegara a identificar la Afrodita Urania con el amor conyugal por considerarse en algunas tradiciones (también helenísticas o alejandrinas) a Himeneo, el dios de las bodas, hijo de esa musa, como recuerda por ejemplo Catulo (Carmina, 61).

Por esta peculiar reinterpretación de las Afroditas platónicas el género del epitalamio incluyó la invocación a una nueva Afrodita o Venus, que sus autores bautizan con el calificativo de "Bona», al hacerla inductora del "amor bonus», traducido en ocasiones como 'amor honesto'. En el primero de sus epitalamios, por ejemplo, Catulo la presenta conducida por Himeneo:

Huc aditum ferat

Dux bonae Veneris, boni

Coniugator amoris ${ }^{91}$.

['Encamine hacia aquí sus pasos el guía de la Venus buena, el que une el buen amor']

El poeta latino vuelve a apelar a la misma Venus (también en el mismo epitalamio) para caracterizar el tipo de deseo, bastante moderado, que debe sentir el novio cuando entra en la cámara nupcial pensando en consumar el himeneo y en arrebatar la virginidad a la novia:

Non diu remoratus es,

Iam venis. Bona te Venus

Iuverit, quoniam palam

Quod cupis cupis et bonum

Non abscondis amorem ${ }^{92}$.

['No has tardado demasiado; ya llegas. A ti te ayuda la Venus Buena, porque abiertamente deseas lo que deseas y no escondes el buen amor'].

En ese contexto está claro que el «bonus amor» es un amor menos lascivo y carnal pero que incluye también la relación sexual entre los cónyuges. Catulo presenta al novio de su epitalamio con una lujuria contenida pero que tampoco sabe disimular por ansiar la consumación del himeneo. El poeta latino no olvida la inserción, en unos versos anteriores, de la ceremonia, habitual en el género, de la soltura de la cinta de la novia para indicar que su poseedora consiente en rendir su virginidad.

Pensando precisamente en esta caracterización de la "Venus Bona» (la Venus conyugal por excelencia), San Agustín, en su obra De civitate Dei (IV, 16), llega

90. Para las dos estatuas y su simbología, véase Miguel Ángel Elvira Barba (2008: 235 y 241): «Según Alciato, la tortuga que Fidias colocó bajo el pie de su Afrodita Urania sería en rea- lidad una advertencia a las mujeres para que no se muevan de casa y se ganen buena fama». 91. Catulo (2009: 310).

92. Catulo (2009: 314). 
a distinguir una tercera Venus, que él llama conyugal, a caballo entre una casta $\mathrm{o}$ virgen y otra meretriz. En el siglo XVI , por ejemplo, en el Tratado de las vestales (de hacia 1562), Alvar Gómez de Castro entendió que nuestro padre de la iglesia había situado el amor conyugal como un amor intermedio entre las dos Afroditas de Platón:

San Agustín [...] dice de opinión de algunos que esta Vesta era Venus, cuyos fuegos también son castos como deshonestos, y hace memoria de las tres maneras de Venus virginal, conyugal y meretricia, que los griegos por otros nombres llamaron celestial, honesta y vulgar ${ }^{93}$.

Boscán parece basarse en esa tradición sobre el amor conyugal para exaltarlo prácticamente en los tres libros en que distribuyó su obra cuando decide darla a luz en 1542. Es la misma tradición que también recuerda cuando en la fábula de Leandro describe el enamoramiento de los personajes o su himeneo posterior. Cuando puede invocar la "Venus Bona», porque también lo hace Museo

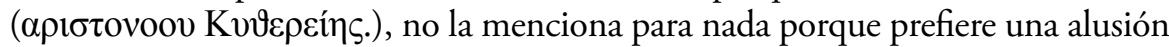
más clara y explícita al matrimonio. Como traductor de El Cortesano, conocía el pasaje en que su autor recomienda a las damas no casadas amar «a hombre con quien pueda casarse» (III, 57) ${ }^{94}$.

Los neoplatónicos del Renacimiento consideraron que el amor espiritual (el de la Afrodita Urania) sólo permitía la visión pero nunca el tacto (otra cosa era el beso), porque tenían la convicción de que el amor carnal (el de la Afrodita Pandemo), al pretender la completa posesión física de la amada, convertía a quien lo experimentaba en una bestia y lo sumía también en una especie de enfermedad (Ficino en su comentario lo llama «amor ferinus») ${ }^{95}$. Pero esos neoplatónicos no se refirieron casi nunca al amor conyugal porque seguramente no supieron vencer los muchos prejuicios que sobre él pesaban desde la Edad Media.

En su comentario del diálogo platónico, Marsilo Ficino respeta la distinción entre las dos Afroditas pero llega a considerar a las dos igualmente honestas y merecedoras de elogios (II, 7). Identifica a la Afrodita Urania con la inteligencia que

93. Justo García Sánchez (1994: 184). En sus comentario a la obra De Nuptiis Philologiae et Mercuri et de Septem artibus liberalibus libri novem 862, 11), Remigio de Auxerre sólo distingue dos Venus: «Duae sunt Veneres, una casta et pudica quae praest honestis amoribus, quae etiam fertur uxor Vulcani, altera voluptuarias libidum dea, cuius filius est Ermafrodita. Sic etiam sunt duo amores, alter bonus et pudicus quo virtudes et sapientia amantar, alter impudicus et malus, quem ad distinctionem boni amoris pluraliter amores dicimus" ['Dos son las Venus, una casta y púdica, que prevalece en los amores honestos, que también trae la mujer de Vulcano, y otra diosa de los placeres, cuyo hijo es Hermafrodita. Así también hay dos amores, uno bueno y púdico, por el que se aman las virtudes y la sabiduría, y otro impúdico y malo, al que llamamos amores en plural para distinguirlo del buen amor']. El pasaje lo reproduce Jane Chance (1994: 281).

94. Baldassare Castiglione (1994: 422).

95. Recuérdese que Hero, ya en la versión de Museo, reconviene a Leandro por haberse atrevido a cogerla de la mano y a tirar de su vestido. Boscán mantiene esa escena en su versión de 
sitúa en la mente angélica y a la Afrodita Pandemo con la capacidad de engendrar que atribuye al alma del mundo. Piensa que la primera Afrodita pretende la comprensión de la belleza de Dios y la segunda la creación de esa misma belleza en los cuerpos. Entiende que la Afrodita Pandemo solo podrá ser mala si el que la pone en práctica busca la generación con mujeres más allá de lo normal y acaba prefiriendo la forma del cuerpo a la belleza del espíritu. En ningún momento llama conyugal a esta Afrodita, pero deja clara su posible relación con el matrimonio cuando establece como su prioridad básica la procreación y establece evidentes relaciones con la Venus "Aeneadum generatrix» ('madre de los descendientes de Eneas') que Lucrecio invoca en el proemio de su De rerum natura ${ }^{96}$.

Al final de la obra, a propósito del discurso de Diótima, el médico florentino vuelve a introducir una distinción similar entre dos tipos de amores, que vincula a dos demonios, el Calodemón (demonio bueno o bello) y el Cacodemón (demonio malo), que juzga también buenos porque el segundo pretende la "procreación de hijos», "tan necesaria y honesta como la búsqueda de la verdad ${ }^{97}$. Como había hecho con la Afrodita Pandemo, cree que el Cacodemón llega a ser propiamente malo si abusamos de él y lo desviamos hacia tareas más viles. Tampoco en este caso se refiere explícitamente al matrimonio para identificar a este tipo de amor, pero también establece una evidente conexión con ese sacramento al atribuirle como fin principal la procreación de hijos. Es posible que Ficino para la consideración de esa Afrodita Pandemo como buena y honesta se haya basado en la «Venus Bona» de los epitalamios ${ }^{98}$.

Los humanistas, sin embargo, tendieron a exaltar el amor conyugal tanto en sus escasas obras teóricas sobre la vida familiar como en sus poemas líricos, según lo demuestran León Battista Alberti y Giovanni Pontano, porque plantearon la relaci ón entre los esposos como si fuera una auténtica relación de amistad (de ahí, por ejemplo, que León Hebreo usara para su fórmula los tres tipos de amistad que Aristóteles había distinguido en su Ética a Nicómaco). Pero para esa exaltación del amor conyugal se basaron en la misma tradición platónica que los filósofos y médicos del Renacimiento pero que les llegó por otros textos.

Para acentuar la honestidad de esa Venus, el poeta barcelonés elimina, como ya también había hecho Tasso, una de las ceremonias típicas de los himeneos que incluye Museo en la parte correspondiente de su epilio (y Catulo, como hemos visto, en el epitalamio en que hace intervenir a la Venus Bona): la ceremonia en que el novio desata el ceñidor de la novia, que es el símbolo de su virgi-

la fábula por más que había leído en la obra de Castiglione que el amante, una vez ya se ha ganado la confianza de dama, puede tomarla de la mano y mantenérsela cogida sin incurrir en ninguna falta (IV, 62).

96. Erwin Panofsky (1980: 201).
97. Marsilio Ficino (1986: 141).

98. Para otras distinciones de Afroditas o Venus, como la que hace Pico Della Mirandola entre «Venere Celeste I», «Venere Celeste II y "Venere Volgare», en el Renacimiento italiano, véase Erwin Panofsky (1980: 189-237). 
nidad. Museo introduce la típica y tópica ceremonia después de atribuir a Hero la invitación que hace a su amante de desfallecer en sus brazos (también parece

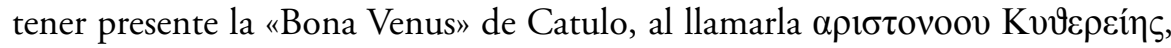
'Citerea o Venus excelente'):

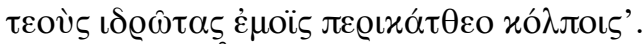

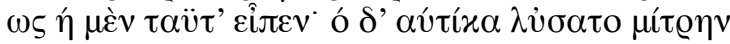

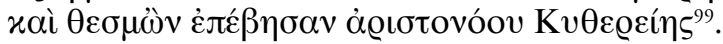

['Deposita tus sudores en mi pecho'. Esto es lo que dijo ella, y él en seguida le desató la cinta y cumplió con el rito de la Citerea excelente'].

Guillermo de Mara sigue ofreciendo en este pasaje una traducción bastante literal, pero acaba optando por un eufemismo cuando elimina la referencia directa a la diosa Venus:

'nostris ecce tuos sinibus compone madores'.

Sic ait. At iuvenis zonam de corpore soluit

Tractaruntque deae leges ac iura benigne ${ }^{100}$.

['Aquí deposita tus sudores en mi regazo'. Así dijo. Y el joven [Leandro] desató del cuerpo la cinta y [los dos] pusieron en práctica las leyes de las diosas y los juramentos benignos']

Boscán, por su parte, amplifica el parlamento de Hero y suprime, en el mismo sentido que Tasso, esa acción del novio posiblemente por parecerle una alusión demasiado directa y explícita a la pérdida de la virginidad de la muchacha:

«Descansa ya, mi bien, en estos brazos,

Echa acá tu sudor y tus trabajos [...]»

A tanto amor, Leandro ¿qué pudiera

Responder con palabras respondiendo?

Calló de puro tierno y derretido

Un rato, casi de sentido fuera.

Tras esto, con dulzuras entrañables,

A todo satisfizo de tal arte,

Que'l amor de los dos quedó en un punto,

Correspondiente'l uno con el otro.

Y así fue'l casamiento celebrado,

Y quedaron entrambos, desde'ntonces,

Atados a la ley del matrimonio ${ }^{101}$.

99. Museo (2002: 28).

100. Musaei vetustissimi Poetae Opusculum de amoribus Leandri et Herus, fol. [d vij vo].

101. Boscán, ed. cit., p. 309. 
Para este pasaje al menos el barcelonés ha podido tener en cuenta no sólo la versión latina de Guillermo de Mara sino también los comentarios de Giovanni Vatelli que la acompañan desde la primera edición de 1511. Mara, como hemos visto hace un momento, sustituye la referencia a la diosa Citerea por otra más vaga y general a las «deae» (a la propia Venus pero también a Juno), y prefiere un lenguaje más jurídico para indicar la consumación del matrimonio, como por ejemplo había usado Giraldi Cinzio (quien tampoco supo abstenerse de las alusiones sexuales más directas) en algunas de sus Sylvae epitalámicas publicadas en Ferrara en 1537:

Te decet hoc etiam, Veneris iam gaudia carpe,

Quae tibi mille parat gaudia, mille viro.

Ludite iam pueri pariter, sudate medullis,

Soluite concordes debita iura toro ${ }^{102}$.

['A ti también conviene esto, goza ya de los placeres de Venus, a ti te ha preparado mil placeres, otros mil al esposo. Jugad ya como nińos, sudad hasta las medulas, cumplid concordes los juramentos debidos al lecho'].

Vatelli en sus escolios justifica la manera en que Mara ha traducido los versos griegos aduciendo sobre todo motivos de tipo moral:

Tractaruntque] Honesta de more suo periphrasi rem obscenam subticuit ${ }^{103}$.

'[Pone en práctica] Calla la cosa obscena por la honesta con su perífrasis de costumbre'].

En el escolio a un verso anterior en que el traductor se refiere directamente al tálamo conyugal, cuando el poeta griego hace alusión al aposento, Vitelli parafrasea el pasaje en unos términos que explican aún mejor los empleados por Boscán:

In quo curantur vincula iugalia, i. leges et debita matrimonii ${ }^{104}$

['en el que [los amantes] se ocupan de los lazos matrimoniales, esto es, las leyes y obligaciones del matrimonio'].

Para su poema en pareados (publicado en París en 1541), Clément Marot se ciñe muy estrechamente al texto original y al hacerlo demuestra no haber usado la versión latina de Guillermo de Mara (tal vez pudo haber consultado la de Aldo Manuzio, habitualmente atribuida a Marco Musuro) porque menciona

102. El texto lo reproduce Jesús Ponce Cárdenas (2006: 246).

103. Musaei vetustissimi Poetae Opusculum de amoribus Leandri et Herus, fol. [d viij ro].

104. Musaei vetustissimi Poetae Opusculum de amoribus Leandri et Herus, fol. [d vij ro]. 
directamente a la diosa Venus para darle un calificativo con el que en principio

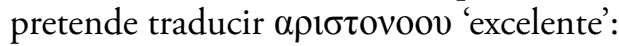

Leandre adonc la saincture impolluë

Qu'elle portait, soudain luy a tolluë

D'autour du corps et entrerent tous nuds

Aux saintes loix de la douce Venus ${ }^{105}$.

Para la escena del recibimiento de Leandro por Hero en la costa de Sestos (escena que forma parte del himeneo secreto entre los dos), Boscán ha atribuido a Hero un gesto que ha tomado de la tradición de los evangelios sobre María Magdalena y que ya antes que él habían utilizado Baldricus Burgulianus y Tasso, seguramente también para atenuar la parte menos buena y honesta de la Venus conyugal. Para toda la escena, que comprende dos partes (una primera en la playa y una segunda en el aposento de Hero), el poeta barcelonés ha utilizado tanto a Museo como a Ovidio (y en algunos detalles, como veremos en seguida, también la Leandraride de Giovanni Girolamo Nadal y la Història de Corella). Es necesario volver a leer la escena en esas dos partes en que la hemos dividido para poder percibir mejor esos cambios que introduce nuestro poeta, pensando casi siempre en su moralización de la fábula:

Y así, [Hero] abajando con medrosos pasos

A una puerta, que alli'staba, pequeña,

Junto a la orilla, donde daba el agua,

En l'arena asentado vio su'sposo,

Goteando la mar de sus cabellos,

Alcanzándos' un huelgo con el otro,

No pudiendo mostrar sino cansancio,

Teniendo tanto que mostrar entonces.

Y así corrió a tomalle entre sus brazos,

Abrazándole muy estrechamente,

Sin poderle dezir ni una palabra.

Y después ya que'n esto'stuvo un poco,

Empezó a tomalle por la mano,

Para llevalle arriba a su aposiento.

Y en tiniéndol'allí, viéndole laso,

Y ensalgado de l'agua y de l'arena,

Con sus cabellos, le fregaba el rostro,

Con su tranzado l'alimpiaba el cuello,

$\mathrm{Y}$ con sus mangas anchas de camisa

Los brazos y los pechos enjugaba.

$\mathrm{Y}$ en el lugar do las amargas aguas

Su vileza y hedor dejado habían,

Otras aguas d'olor puso preciosas,

105. Histoire de Leander et H ero, en Oeuvres de Clement Marot, tomo III, Alahate, 1731, p. 133. 
Como aquellas que Venus de sus manos,

Compuso y revolvió para Vulcano,

Cuando con sus regalos y dulzuras

Le hizo fabricar las fuertes armas

Con las cuales a Turno mató Eneas ${ }^{106}$.

En ese encuentro ha reproducido, siguiendo las dos heroidas de Ovidio, los abrazos y besos que se dan nuestros amantes. Pero ha añadido dos detalles que ha captado de autores medievales. El primero de esos detalles es la manera, cogido de la mano, en que Hero se lleva a Leandro a su aposento. De todos los autores conservados que tratan la fábula sólo lo ofrece Nadal:

Po' il prese a mano, e quivi il menò a casa

Et in talamo intrato, adorno quanto

Deceva a sola e divite rimasa ${ }^{107}$.

El otro detalle es la referencia a la puerta exterior de la torre que Hero atraviesa cada vez que sale a la playa a recibir a Leandro. Una puerta del mismo estilo sólo la menciona Corella pero ya en la escena final en que la muchacha baja al mar para secar y abrazar el cadáver de Leandro antes de morir sobre él clavándose un puñal:

E, devallant de la torre per aquella porta secreta que Leànder entrar solia... ${ }^{108}$

Es verdad que Museo también alude a una puerta en la torre de Hero pero parece identificarla con una interior que los amantes han de cruzar para entrar en el aposento de la muchacha:

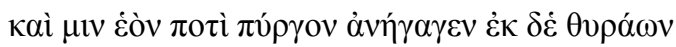

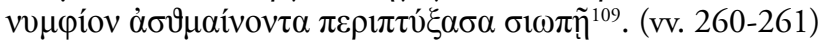

['Y a él [Hero] lo llevó arriba a su torre y junto a la puerta abrazó en silencio al esposo exhausto'].

Uno de los dos traductores al latín del epilio griego, Guillermo de Mara, ofrece una versión bastante literal del original:

Hunc mox aeream virgo deduxit in arcem

Atqui pro valvis primoque in limine sponsum

Dulcis anhelantem tacite est complexa puella ${ }^{110}$.

['La doncella lo condujo en seguida a la torre de bronce y delante las puertas y en su entrada la dulce muchacha abrazó al esposo jadeante'].

106. Boscán, ed. cit., p. 308.

107. Nadal, ed. cit., p. 92.

108. Corella, ed. cit., p. 170.
109. Museo, ed. cit., p. 27.

110. Musaei vetustissimi Poetae Opusculum de amoribus Leandri et Herus, fol. [d v ro]. 
Boscán, por tanto, aparte de a Museo, tuvo también en cuenta a Corella (y no será la única vez) o a un texto (posiblemente de origen italiano) que pudiera servir de modelo a los dos (y también a Bernardo Tasso, como comprobaremos después). Tampoco cabe descartar de manera definitiva que nuestro poeta usara directamente la prosa del mosén valenciano porque la pudo leer en Barcelona al menos, que sepamos, en uno de los manuscritos de la ciudad condal que la ha transmitido. Es el misceláneo Jardinet d'orats.

En la segunda parte del recibimiento, Boscán ha añadido un detalle que no aparece en ninguno de los textos antiguos que han conservado la fábula. Hero no sólo limpia las distintas partes del cuerpo de Leandro con las mangas de la camisa sino también el rostro y el cuello del muchacho con sus cabellos (peinados en trenzas o "tranzados»). Después de describir toda la escena, el barcelonés precisa que la muchacha ha estado derramando lágrimas como parte de los mimos que ha dedicado a su amante (da a entender, pero no lo dice explícitamente, que ha mojado con ellas también el rostro y el cuello de Leandro que ha secado con sus cabellos trenzados):

Después que así le estuvo regalando

Con sus lágrimas tiernas y gozosas (vv. 2204-2205) ${ }^{111}$.

En su poema Baldric de Bourgueil atribuye a nuestra heroína un gesto muy similar pero no en esa escena sino en una posterior en que recibe el cadáver de su amante: Hero vierte sobre él lágrimas que seca también con sus cabellos. En los dos casos el detalle recuerda una escena de los evangelios recogida en distintas formas y variantes por sus autores. Baldric, sin duda y como hemos visto ya, ha tenido en cuenta la versión en que una mujer pecadora derrama lágrimas sobre los pies de Jesús y se las enjuga con sus cabellos (Lucas, 7, 36-50). Bernardo Tasso, en cambio, como también hemos comprobado, ha seguido las versiones de Mateo (26, 6-13) y Marcos (14, 3-8) al elegir los cabellos (y no el cuerpo o los pies) como la parte de su amante ungida por Hero y al usar el mismo adjetivo que los dos evangelistas para calificar el perfume.

Boscán ha preferido también la versión de Lucas al presentar a Hero derramando lágrimas sobre el cuerpo vivo de su amante. No parece haber leído a Baldric pero sí ha usado a Bernardo Tasso, con quien coincide en la adopción del mismo adjetivo para el líquido perfumado, que ha tomado directamente de los evangelios: «aguas... preciosas» (v. 2198). Da la impresión de haber decidido cambiar la escena de la unción por influencia del poeta italiano.

El poeta barcelonés pudo haber añadido este detalle pensando, como lo había hecho Tasso, no sólo en anticipar la muerte de Leandro sino también en la redención y salvación de los dos amantes. Al presentar el enamoramiento de los

111. Boscán (1992: 308). 
dos personajes presidido por esos dos tipos de amor (el sano y el insano o pestilente), ha querido exculparlos del segundo haciéndolos protagonizar una escena que recuerda la de Jesús en Betania o en Galilea. De ese modo se explica que, como veremos en seguida, haya pensado en un solo lugar para ellos en el más allá: un lugar con el que deja claro que los amantes se salvan y no padecen ningún tipo de castigo o purgatorio (y también un lugar en que han podido dejar de sentir el amor insano o pestilente).

Pero es que además Boscán compara las «aguas... preciosas» de Hero con otras con las que Venus habría ungido a Vulcano cuando hubo de convencerlo de que fabricara las armas para su hijo Eneas. El barcelonés ha confundido el episodio en que Venus, efectivamente, emplea sus encantos (pero ningún tipo de perfume o ungüento) para persuadir a su marido (Virgilio, Eneida, VII, 369454) con otro episodio en que también Venus lava y unge pero no el cuerpo de su marido sino el de su hijo Eneas para convertirlo en un dios (Ovidio, Metamorfosis, XIV, 600-608). Si Boscán ha confundido esos dos episodios es porque el segundo Ovidio lo introduce tras narrar el desenlace del primero (el momento en que Eneas con las armas que le ha entregado su madre mata a Turno). En el episodio al que alude directamente el barcelonés Venus lava primero a su hijo en el río Numicio y después unge su cuerpo con perfumes divinos:

Hunc iubet Aeneae, quaecumque obnoxia morti,

Abluere et tacito deferre sub aequora cursu.

Corniger exsequitur Veneris mandata suisque,

Quidquid in Aena fuerat mortale, repurgat

Et respergit aquis: pars optima restitit Illia.

Lustratum genetrix divino corpus odore

Unxit et ambrosia cum dulci nectare mixta

Contigit os fecitque deum... (XIV, 600-607) ${ }^{112}$.

['Le manda [al río Numicio] purificar a Eneas de cuantas partículas tiene adheridas a la muerte y anegarlas en el mar en silenciosa corriente. El río con cuernos ejecuta las órdenes de Venus y limpia y rocía con sus aguas todo lo que es mortal: su mejor parte permanece en él. Su madre ungió su cuerpo purificado con un perfume divino y le tocó la boca con ambrosía mezclada con un dulce néctar y lo hizo dios...'].

El poeta barcelonés también podría haberse confundido con la escena en que Homero narra la manera en que la diosa Hera seduce a Zeus para desviar la atención de su marido y ayudar de ese modo a sus protegidos los griegos en la guerra de Troya. Es una escena que ya hemos estudiado al principio del trabajo cuando proponíamos las posibles fuentes de Museo para su escena de la unción. Esta escena que introduce Homero en la Ilíada Virgilio la imita muy claramente

112. Ovidio (1983: 152). 
en su Eneida al incluir una muy similar entre Venus y Vulcano. En los dos poemas una diosa (Hera y Venus) engańa a su marido, otro dios (Zeus y Vulcano), con el fin de lograr un beneficio para sus protegidos o hijo (los griegos y Eneas) en la misma guerra de Troya. Las dos diosas en cuestión utilizan sus encantos para la seducción, pero mientras Venus tiene suficiente para conseguirla con sus abrazos y caricias Hera necesita de la unción tanto de su cuerpo como de sus cabellos y del cinturón de Afrodita ${ }^{113}$. Pensando en la escena de la Ilíada Boscán debió creer que la de la Eneida también contenía una unción.

El autor del Ovide moralisé interpreta el episodio de las Metamorfosis de diversas maneras. Primero ofrece la explicación más literal al recordar los efectos que provocan las aguas y el ungüento divino (no son otros los efectos que la vida perdurable). Después propone otra más cristológica al identificar a Eneas con Jesús por conseguir los dos, gracias a sus respectivos ungüentos, la inmortalidad (y el segundo también la salvación). Dentro de esta segunda explicación acaba relacionando la unción de Eneas con la de Jesús en el santo sepulcro y trae a colación el descenso del hijo de Dios a los infiernos para rescatar a sus fieles y conducirlos al paraíso:

Por espurgier de mort amere
Fu en crois purgiez voirement.
Li cors Dieu puis fu d'aroment
Ou sepulchre oins et enbasmez,
Et l'ame ala por ses amez
Visiter l'infernal closture,
Si le traist de la chartre obscure
Et s'en revint a grant Victoire.
Si resuscita, c'est la voire.
Or est ses cors deïfiez
Et aus sains cieulz glorefiez (XIV, 4724-4734) ${ }^{114}$.

El anónimo autor había aclarado que las aguas purificadoras (también Boscán se refiere a las aguas en general) representan los traidores que han condenado a muerte a Jesús porque unas y otros posibilitan su muerte y con ella la rerdención de toda la humanidad. En páginas anteriores habíamos aducido el ejemplo de un autor del siglo XVI que recoge esta tradición al proponer la identificación del ungüento precioso con la cruz salvadora de Cristo:

Li fel qui à mort le jugerent

Sont les iaues que le purgerent

De quanqu'avoit en li morté (XIV, 4717-4719) $)^{115}$.

113. Un buen análisis de los dos episodios ofrece María Emilia Cairo (2010) También en la Iliada (XVIII, 368-610) Homero reproduce el episodio en que Tetis pide a Hefesto en su palacio una armadura para su hijo Aquiles.
Pero el episodio transcurre en presencia de la esposa del herrero cojo, una de las Gracias, y no incluye ningún tipo de seducción.

114. C. de Boer (1966:. 130).

115. C. de Boer (1966: 130). 
Boscán ha dado a la escena de la unción de Leandro por Hero un valor especial al recordar la de dos seres divinos, Jesús y Eneas. Es muy evidente que ha procurado divinizar a su personaje principal al someterlo a un proceso de purificación en el que se elimina de su cuerpo la mortalidad y la carnalidad (es el mismo proceso al que el río Numicio somete al cuerpo de Eneas con sus aguas y también con las del mar). Si ha elegido para la unción de Leandro tanto el modelo evangélico como el clásico es porque ha imaginado para él y su amada el mejor de los destinos más allá de la muerte: el paraíso de los Campos Elíseos.

Los autores medievales ya preveían ese tipo de purificaciones que los dioses practicaban entre ellos. Uno de los comentaristas de la obra De nuptiis Philologiae et Mercurii de Marciano Capella, Remigius of Auxerrre considera la laguna Estigia como un lugar en cuyas aguas todos los dioses suelen purificarse para adquirir su naturaleza celeste o divina. Al establecer su genealogía, presenta a la laguna en cuestión (también río para otros) con la esposa de Neptuno y nodriza de los dioses (es curioso que las aguas que obran el milagro de la pruficación lo sean de una diosa desposada):

Omes dii de terris per purgationem, quam Estix significat, caeleste meruerunt consortium $^{116}$.

['Todos los dioses de la tierra reciben su parte celeste desde la tierra a través de la purgación, que significa Estigia’]

Para el episodio de la muerte de Leandro Boscán también se ha basado en el relato de Corella porque pretendía ponderar el gran amor que sentían sus dos personajes para considerarlos salvados también gracias a él (en el episodio de la unción de Jesús a la mujer la salva especialmente su amor y fe en el hijo de Dios). El poeta barcelonés ha tomado claramente del valenciano dos ingredientes que también pudo haber leído en la muerte de Céix narrada por Ovidio en sus Metamorfosis: la determinación del agónico nadador de dirigir la mirada hacia el lugar en el que supone está la amada y la pronunciación de su nombre en el instante de la muerte (como también ocurre en la de Orfeo). En pequeños detalles Boscán parece demostrar un conocimiento directo de la prosa de Corella (si el Leandro del barcelonés, por ejemplo, no puede acabar de articular el nombre completo de Hero es porque el del valenciano lo ha hecho hasta la última sílaba):

\footnotetext{
Empezaron sus brazos a vencerse,

Sus piernas anduvieron desmayando,

Entrábale la muerte con el agua

Y dél a su placer tornaba el tiempo.

Él, viéndose morir entre'stos males,
}

116. El pasaje lo cita Jane Chance (1994: 279-280). 
La postrer cosa que hizo el desdichado

Fue alzar los ojos a mirar su lumbre.

Y aquel poco de aliento que tenía

Echole todo en un gemido bajo,

Envuelto en la mitad del nombre d'Hero.

$\mathrm{Y}$ allí un golpe le dio del mar tan bravo,

Que le sorbió del todo en un instante,

Y en este mismo punto un torbellino

Acabó de matar la lumbrecilla,

Testigo fiel y dulce mensajera

D'estos fieles y dulces amadores ${ }^{117}$.

Boscán, al igual que Tasso, no sigue en este punto a Museo (extrañamente sí lo había hecho Corella, como hemos tenido ocasión de comprobar). En ningún momento dice que Leandro junto a la vida haya perdido en el mar su amor porque lo considera aún activo después de su muerte. Si en el poeta griego es al final el fuerte viento el que apaga la lámpara (y el amor que simbolizaba su fuego) y acaba con la vida del amante, en el nuestro, en cambio, es una ola la que lo hace sucumbir porque ha preferido la versión de la muerte de Céix. El barcelonés rechaza la moralización medieval de la fábula (basada, como hemos visto, en la lectura de Museo) y opta por la originaria, la del poema alejandrino perdido, al que directamente se remontan para su interpretación Ovidio y Virgilio (pero también Antípatro de Tesalónica). Por eso ha tenido que insistir más en el tipo de amor (el conyugal) que habían sentido y practicado sus dos amantes: no es que los muestre más castos que en Museo pero sí ha prescindido de detalles íntimos que podían acentuar cierta inmoralidad que ha intentado evitar a toda costa.

El barcelonés se ha inspirado en Corella (más que en las Metamorfosis de Ovidio) cuando al narrar la muerte de Leandro hace que de su boca salga el nombre de Hero a la vez que su último aliento de vida. El pasaje en cuestión lo tuvo muy en cuenta el anónimo autor de un romance incluido en el Cancionero llamado Flor de enamorados (Barcelona, 1562):

Leandro estaba en aquesto,

Su vida se iba apocando:

Zabullole l'agua al hondo;

Murió 1 triste suspirando,

Y con decir «iHero!, ;Hero!»

Su vivir fue acabando ${ }^{118}$.

Para el suicidio de Hero, Boscán ha descartado las versiones tanto de Corella como de Tasso y ha seguido la del epilio griego, que modifica ligeramente, al

117. Citamos por Juan Boscán (1992: 323324), y también por (1999: 393-394).
118. El romance está reproducido por Agustín Durán (1859: 313, núm. 466). Véase también José María Cossío (1998: 157-158). 
sustituir la tradicional torre por una ventana que ya menciona cuando describe a la fiel esposa cayéndose sobre sus barandas en el instante en que reconoce el cadáver de su amante empujado por las olas del mar. Para tan leve modificación sin duda se ha podido inspirar en el triunfo de amor de Petrarca pero también en la versión primitiva del Amadís de Gaula en la que Oriana se arroja desde la ventana de su palacio al conocer la muerte de su caballero ${ }^{119}$.

Para la moralización de la fábula, Boscán se ha inspirado, como hemos visto, en el poema de Tasso, al variar el modelo griego en un sentido muy similar al del italiano, pero al final acaba dando un paso más allá que el italiano, al descartar muy claramente que los dos amantes, ya difuntos, vayan a los "lugentes campi» o "mirthae... silva», porque entiende perfectamente que eran lugares en los que las sombras (más que almas) ya sin vida experimentaban un amor exclusivamente lujurioso que no coincidía ni con el suyo ni con el que había dado a Leandro y Hero. Como buen lector de Virgilio, habría reparado en el complemento con el que el poeta latino acompańaba la expresión "amor durus» para definir ese amor que en los «lugentes campi» sobrevive a la muerte: «crudeli tabe» ('con una cruel peste, enfermedad, epidemia').

Entre el primer y segundo encuentro de los amantes (uno público y el otro privado), el poeta barcelonés ha introducido una larga digresión para justificar los diez días que tarda Hero en encender en su torre la lámpara con cuya luz no sólo ha de hacer la señal convenida a Leandro sino también guiarlo a través de sus aguas hasta la torre donde lo espera. En esa digresión nuestro poeta pone de manifiesto las dotes proféticas de Proteo que recorre la isla de Sestos para ponerlas en práctica entre sus habitantes ( $y$ en especial con nuestra heroína, a quien ya anuncia su final trágico). Pero en la digresión Boscán ha aprovechado también la ocasión para narrar otra historia de amor, con idéntico desenlace, que prefiere a cualquier otra por constituir aún un ejemplo más evidente de amor conyugal. Es la conocida fábula de Orfeo y Eurídice, que relata principalmente de acuerdo con la versión que ofrece Virgilio en sus Geórgicas (IV, 317-528), pero incorporando también detalles de la que Ovidio proporciona en sus Metamorfosis (X, y XI, 1-66), especialmente por lo que respecta a su tratamiento del tema del amor más allá de la muerte. Ovidio incluye en su versión un segundo descenso de Orfeo, tras ser asesinado por las bacantes, al Hades para suponerlo reunido con Eurídice en un lugar al que llama "arva piorum» ('los campos de los justos'), en una más que probable referencia a los Campos Elíseos (Virgilio los había bautizado como «arva laeta», 'campos alegres', para contraponerlos precisamente a los «lugentes campi»). Creemos bastante probable que el poeta barcelonés hubiera dado un paso más que Tasso pensando en ese final que Ovidio previó para los representantes por excelencia del amor conyugal.

119. Para ese tipo de suicidio, véase Bienvenido Morros (2005: 193-216). 
Boscán lleva a cabo con respecto a Tasso una operación similar a la que Joanot Martorell practicó con la prosa mitolológica de Corella cuando prevé para los amantes de su novela (Valencia, 1490) la gloria del paraíso tras sus respectivas muertes. Es la propia Carmesina quien da las intrucciones oportunas para que cuando muera dispongan su cadáver junto al de Tirant:

Comporta al teu cos e meu jo done sepultura, perquè una glòria o una pena aprés la mort sofríen les dues ànimes, les quals un amor havien lligat en vida, e així los cossos morts abraçats estaran en un sepulcre, e nosaltres en glòria, vivint junts en una mateixa glòria ${ }^{120}$.

Boscán sin duda había leído el Tirant lo Blanc, ya en la versión catalana o también en la castellana (Valladolid, 1511), y debió reconocer muchas similitudes entre la historia de esos amantes y la de su fábula. Carmesina y Tirant encarnaban de alguna manera el amor conyugal porque tienen relaciones sexuales cuando han celebrado ya los esponsales ante el Emperador de Constantinopla: han consumado el matrimonio antes de haberlo oficiado. Carmesina, como en algunas versiones de nuestra fábula (no en la de Boscán), muere a causa de su dolor por el fallecimiento de Tirant.

Para completar su particular moralización de la fábula, Boscán, pues, ha elegido los Campos Elíseos también como el destino único para las almas de sus dos protagonistas. Es la constatación final de que el barcelonés ha decidido salvarlos por haber hecho prevalecer entre ellos el amor conyugal. Debe considerar, como otros muchos autores de su época, que los Campos Elíseos son la versión pagana del paraíso cristiano, porque solían situarse debajo del círculo de Júpiter, no demasiado lejos del empíreo ${ }^{121}$. En su particular versión de la fábula ha sabido conjugar sus dos interpretaciones más importantes: la de Museo al considerar el amor de sus personajes como conyugal y también la más antigua (representada por Virgilio, Ovidio y Antípatro de Tesalónica) al presentarlo con la fuerza suficiente para trascender sus propias muertes. Los autores españoles posteriores (especialmente los de la segunda mitad del siglo XVI y principios del XVII) imitaron al nuestro al situar a los dos amantes en sus distintas versiones de la fábula también en los Campos Elíseos. Pero esa es una cuestión que ya abordaremos en otro trabajo.

120. Joanot Martorell (1991: 1157). Sobre la relación de este pasaje con Corella, véase Josep
Pujol (2003: 409-419).

121. Véase al respecto Jane Chance (1994: 274). 


\section{Bibliografía}

Alfonso x El Sabio, General Estoria. Quinta y sexta partes, eds. Belén Almeida y Pedro Sénchez-Prieto, Madrid, Biblioteca Castro 2009, 353 y 354.

Alighieri, Dante, La divina Commedia, testo critico Della Società Dantesca Italiana riveduto col commento scartazzinano riffato da Giuseppe Vandelli, Milán, Ulrico Hoepli, 1984, 41.

Alvar EzQuerra, Antonio, «Mitología clásica y poesía castellana en la época del emperador Carlos», en La mitología clásica en la literatura española, ed. Juan Antonio López Férez, Ediciones Clásicas, Madrid, 2007.

Ausonio. Decimo Magno Ausonio, Opere, ed. Pastorino, UTET, Turín, 1971.

Bersuire, Pierre, Ovidiys moralizatus, ed. F. Ghisalberti, Studi Romanzi, 23 (1933), 117-118.

Boer, C. De, "Ovide moralisé». Poème du commencement du quatorzième siècle, tomo II (livres IV-VI), Wiesbaden, Dr. Martin Sändig oHG, 1966.

Boscán, Juan, Obra completa, edición de Carlos Clavería, Cátedra, Madrid, 1992.

—, Poesía, edición de Pedro Ruiz Pérez, Akal, Madrid, 1999.

Burgulianus, Baldricu / BURGEIL, Baudri, Carmina/Poèmes, ed. Jean-Yves Tillitte, vol. II, París, Les Belles Letres, 2002.

CaIro, María Emilia, "El pedido de armas de Venus a Vulcano (Eneida, VIII, 370-406): algunos intertextos», Circe de clásicos y modernos, XIV (2010), en http://www.scielo.org.ar/scielo.php.

CaravagGi, Giovanni, «Hacia la invención de la epístola poética», en La epistola poética del renacimiento español, coord. Lara Garrido, Fundación de la Universidad de Málaga, Analecta Malacitana, 2009.

Castiglione, Baldassare, El cortesano, ed. Mario Pozzi, Madrid, Cátedra, 1994.

Catulo, Poesías, edición bilingüe de José Carlos Fernández Corte y Juan Antonio González Iglesias, Madrid, Cátedra, 2006.

—, Poesías, edición bilingüe de José Carlos Fernández Corte y Juan Antonio González Iglesias, Madrid, Cátedra, 2009.

Chance, Jane, "The Uxorious Gods in Remigius of Auxerre's Neo-Stoic Commentary on Martianus Capella", 274-281.

—, "The Uxorious Gods in Remigius of Aucerre's Neo-Stoic Commentary on Martianus Capella», en Medieval Mythography. From Roman North Africa to the School of Chartres, A.D. 433-1177, Florida, University Press, 1994, 274-275.

Chariton, Le roman de Chaireas et Callirhoé, ed. Georges Molinié, París, Les Belles Lettres, 1979.

Cingolani, M., Joan Roís de Corella: la importància de dir-se honest, Valencia, Eliseu Climent, 1998.

CoRella, Joan Roís, "La istòria de Leànder y Hero», en Les proses mitològiques, ed. crítica de Josep Lluiís Martos, Alacant/Barcelona, Institut Interuniversi- 
tari de Filologia Valenciana- Publicacions de l'Abadia de Montserrat, 2001, 151-173.

Cossío, José María, Fábulas mitológicas en España, Madrid, Istmo, 1998, vol. I. -, "Sobre la transmisión del tema de Leandro y Hero", Revista de Filología Española, 16, 1929, 174-175

Daniello da Lucca, Bernardino, L'expositione sopra la "Commedia» de Dante, ed. Robert Holänder, Darmouth College, University Press of New England, 1989, 302.

DuRän, Agustín, ed., Romancero general, Madrid, Atlas, 1859, vol. I..

Edmons, J. M, The Greek Bucolic Poets, Harvard University Press, Londres, 1977.

Encina, Juan del, Obras completes, ed. Ana María Rambaldo, Madrid, EspasaCalpe, 1978, vol. II.

Elvira BaArba, Miguel Ángel, Arte y mito. Manual de iconografía clásica, Silex, Madrid, 2008.

Engelbrach, William, Filologie in de Destiende eeuw: De Bursarii super Ovidios van Magister Wuillen von Orléans, vol I, 2003, 50-59.

Fernández Corte, José Carlos, y González Iglesias, Juan Antonio, eds., Catulo, Poesias, Madrid, Cátedra, 2006.

Ficino, Marsilio, De amore. Comentario a "El banquete" de Platón, traducción y estudio preliminar de Rocío de la Villa Ardura, Madrid, Tecnos, 1986.

—, Omnia divini Platoni opera tralatione Marsili Ficini, emendatione et d Grecum codicem collatione Simonis Grynael summa diligentia repurgata, Lyon, 1548.

Flamini, F., «La Historia de Leandro y Hero' e l'ottava rima di Giovanni Boscán», en Studi di Storia letteraria italiana e straniera, Livorno, 385-417.

Fontana ElboJ, Gonzalo, «La sección áurea, estructura numérica del Leandro y Hero de Boscán", Cuadernos de Investigación Filológica, XI (1985), 71-77.

—, «Algunas notas sobre la relación entre Boscán y Bocángel en sus poemas de Hero y Leandro», Cuadernos de Investigación Filológica, 15 (1989), 71-86.

Fulgentius, Fabius Planciadius, Opera, ed. R. Helm, Stuggart, Teubner, 1970.

Galán Vioque, Guillermo, ed. y trad., Antología Palatina. II: La Guirnalda de Filipo, Madrid, Gredos, 2004.

García Sánchez, Justo, Las vestales romanas. Tratado de Álvar Gómez de Castro, Oviedo, Universidad, 1994.

Garrido y VALls, Josep-David, «La traducción catalana medieval de les Heroides d'Ovidi", Faventia, 24 (2002), 37-53.

Goelzer, Henri, Eneide, I, París, Societé d'Edition «Les Belles Artes», 1959.

Gómez Redondo, Francisco, Antología poética comentada, Madrid, Edaf 2004, 184.

Gregson Davis, N., «Cupid at the Ivory Gates: Ausonius as a Reader of Vergil's Aeneid», Colby Q30, 1994. 
Homero, Ilíada, ed. Luis M. Macía Aparicio, Consejo Superior de Investigaciones Científicas, Madrid, 2009, vol. III.

—, Odissea, ed. Alfred Heubeck, traducción al italiano de G. Aurelio Privitera, Milán, Mondadori, 2004, vol. III.

Lacroix, Daniel y WaLter, Philippe, Tristan et Iseut Les poèmes français. La saga norroise, 1989.

Lucano, Farsalia: de la Guerra Civil, ed. Rubén Bonifaz Nuño y Amparo Gaos Schmidt. Universidad autónoma de México, 2004.

Marlowe, Cristopher, The complete Poems and Translations, ed.Stephen Orgel, Londres, Penguin Classics, 2007.

Marot, Clément, Histoire de Leander et Hero, en Oeuvres de Clément Marot, tomo III, Alahate, 1731, 133.

—, «L'Hystoire de Leander et de Hero», en OEuvres completes, ed.François Rigolot, París, GF Flammarion, 2009, 76-93.

Martorell, Joanot, Tirant lo Blanc, ed. Martín de Riquer, Barcelona, Ariel, 1991.

Martos, Josep Lluís, Fonts i seqüència cronològica de les proses mitològiques de Joan Rois de Corella, Alacant, Universitat d'Alacant, 2001.

Menéndez Pelayo, Marcelino, Antología de poetas líricos castellanos, Consejo Superior de Investigaciones Científicas, Madrid-Santander, 1945.

Mitógrafos Vaticanos, en Scriptores rerum mythicarum latini tres Romae nuper reperti, ed. G. H. Bode, Hildesheim, Geog Olms Verlagsbuchhandlung, 1968.

Montgomery, Thomas, y Baldwin, Spurgeon W., eds., El nuevo Testamento según el manuscrito escurialense I-j-6, Anejos del Boletín de la Real Academia Española, Madrid, 1962

Montes de Cala, José Guillermo, ed., Museo, Leandro y Hero, Madrid, Gredos, 1994.

Morros, Bienvenido, "Oriana y Melibea: de mujer a mujer", Revista de literatura medieval, 17 (2005), 193-216.

Moya Del Baño, Francisca, Estudio mitográfico de las «Heroidas» de Ovidio, Murcia, Universidad de Murcia, 1969.

Musai Vetustissimi Poetae, Opusculum de amoribus Leandri et Herus, Guilelmo de Mara paraphaste, eruditis Vatelli Coenoliensis commntarris enarratum, París, 1538.

Musaei Grammatici De Hero et Leandro Carmen, 1731, Leiden.

Museo, Leandro y Hero, ed. Antonio Ruiz Elvira, Consejo Superior de Investigaciones Científicas, Madrid, 2003.

Nácar Fuster, Eloíno, y Colengo Alberto, Sagrada Biblia Madrid, Biblioteca de Autores Cristianos, 1944; 2008.

Nadal, Giovanni Girolamo, Leandreride, ed. Emilio Lippi, Antenore, Padua, 1996.

Nonos de Panopolis, Les Dionysiaques (chants XXX-XXXII), ed. Francis Vian, París, Les Belles Lettres, 1997, vol. X. 
"Ovide moralisé". Poème du commencement du quatorzième siècle, ed. C. de Boer, tomo $\mathrm{V}$.

Ovidio, Heroidas, ed. y trad. De Antonio Alatorre, México, Universidad nacional de México, 1950.

-, Epistole Eroiche di Ovidio Nasone volgarizzate nel buon secolo Della lengua, secondo la edizione di Sisto Riesinger del secolo XV, ed. G. Bernardoni, Milán, 1842.

-, Heroides. Volgarizzamento Fiorentino trecentesco di Filippo Ceffi, ed. Massimo Zaggia, Sesmel-Edizioni del Galluzzo, 2009.

-, Metamorfosis, ed. Bartolomé Segura Ramos, con traducción de Antonio Ruiz de Elvira, Consejo Superior de Investigaciones Científicas, Madrid, 1983, 3 vols.

PANOFSKy, Erwin, Estudios sobre Iconos estatuasología, Alianza Universidad, Madrid, 1980.

paton, W. R., ed., The Greek Anthology. Book IX, Cambridge-Londres, 1970, vol. III..

Pérez Moya, Juan, Philosophia secreta de la gentilidad, ed. Carlos Clavería, Madrid, Cátedra, 1995.

Petrarca, Trionfi, Rime estravaganti, códice degli Abbozzi ed. Vinicio Pacca y Laua Paolino, con introducción de Marco Santagata, Milán, Mondadori, 1996.

Planciadius Fulgentius, Fabius, Opera, ed. R. Helm, Stuggart, Teubner, 1970.

Platón, Oeuvres complètes. Tome IV. Le banquet, ed. León Robin, París, Les Belles Lettres, 1976.

—, Omnia divini Platoni opera tralatione Marsili Ficini, emendatione et d Grecum codicem collatione Simonis Grynael summa diligentia repurgata, Lyon, 1548.

Ponce Cárdenas, Jesús, "Evaporar contempla un fuego helado": género, enunciación lírica y erotismo en una canción gongoriana, Málaga, Universidad, Anejos Analecta Malacitana, 2006.

Pujol, Josep, "De Pere el Gran a Tristany de Leonis: models retòrics i cavallerescos per la mort de Tirant lo Blanc", en Literatura i cultura a la Corona d'Aragó (s.XIII-XV), eds. Lola Badia, Miriam Cabré y S. Martí, Barcelona, 2003, 409-419.

—, «Les Gloses de Guillem Nicolau a la seva traducción de les Heroides d'Ovidi (1390): una proposta d'identificació", Caplletra, 39 (en prensa).

—, "Noves fonts ovidianes, pràctiques escolars i Boccaccio al Leànder i Hero de Joan Roís de Corella», Cultura Neolatina, en prensa.

Quevedo, Francisco, Antología poética comentada, ed. Francisco Gómez Redondo, Madrid, Edaf, 2004.

Reichenberger, A G., "An emendation of texto f Boscan's Historia de Leandro y Hero", Modern Language Notes, LXV (1950), 493.

—, «Boscan and Ovid», Modern Language Notes, LXV (1950), 379-383. 
Rey de Artieda, Andrés, Discursos, epistolas y epigramas de Artemidoro, ed. Antonio Vilanova, Selecciones bibliófilas, Barcelona, 1955.

Rodrigo del Padrón, Juan, Bursario, Madrid, Universidad Complutense, 1984.

Ruiz de Elvira, Antonio, «Introducción», a Museo, Hero y Leandro, Consejo Superior de Investigaciones Científicas, Madrid, 2003.

Salvo García, Irene, Ovidio en la «General Estoria» de Alfonso X el Sabio, tesis doctoral dirigida por Inés Fernández Ordónez, Universidad Autónoma de Madrid, 2012.

-, "Ovidio y la materia troyana: la Estoria de Troya en la General Estoria de Alfonso X», en Literatura medieval y Renacentista en España. Lineas y pautas, edd. Natalia Fernández Rodríguez y María Fernández Ferreiro, Semyr, Salamanca, 2012, 875-885.

Sebastián Perdices, Irene, y Morros Mestres, Bienvenido, "La Favola di Leandro e d'Ero de Bernardo Tasso: fuentes y contaminaciones con otras fábulas», Studi Rinascimentali, 11 (2013), 173-198.

Servir Grammatici, In Vergili Bucolica et Georgica Commentarii, ed. Georgius Thilo, 3, Hildesheim, Geog Olms Verlagsbuchhandlung, 1961.

Soury, Guy, trad. y ed. Waltz, Pierre, Anthologie grecque. Antohologie palatine. Tome VII (Livre IX, 1-358), París, Les Belles Lettres, 1957.

TAsso, Bernardo, Rime, volumen I: I tre libri degli Amori ed. Domenico Chiodo, Turín, Res, 1995.

Tristan et Iseut. Les poèmes français. La saga norroise, eds. Daniel Lacroix y Philippe Walter, París, Librairie Générale Française, 1989.

Villarubia, Antonio, «Notas sobre el poema Hero y Leandro de Museo», $\mathrm{Ha}$ bis, 3 (2000), 365-401.

Virgilio, Georgics, ed. Richard F. Thomas, Cambridge University Press, Cambridge, 1988.

—, Eneide, ed. Henri Goelzer, París, Société d'Edition «Les Belles Artes», 1959. 